\title{
The Journal of Leukocyte Biology
}

Copy of e-mail notification

zgb5826

Your article (\# 2A0312-169) from The Journal of Leukocyte Biology is available for downloading.

Dear author,

Pages for your manuscript to be published in The Journal of Leukocyte Biology are now ready for proofing.

Please click on this URL address

http://rapidproof.cadmus.com/RapidProof/retrieval/index.jsp

then

Login: your e-mail address

Password:77KiVrgMFc77 (You may copy and paste this case-sensitive password.)

The site contains one (1) file. You will need to have Adobe Acrobat Reader software to read these files. This is free software and is available for user downloading at

http://www.adobe.com/products/acrobat/readstep.html.

This file contains:

Instructions on the Annotation of PDF files

Publication Costs Calculation Sheet

Mandatory Submission and Copyright Transfer Form (complete only if not done previously)

Page proofs of your article

SLB Membership Application (new applicants will be billed at member rates.)

In order to speed the proofing process, we strongly encourage authors to correct proofs by annotating PDF files. Please see the Instructions on the Annotation of PDF files included with your page proofs. Please take care to answer all queries on the last page of the PDF proof; proofread any tables and equations carefully; and check that any Greek characters (especially "mu") have converted correctly. Please read your figure legends carefully.

To ensure that authors are billed properly, Society of Leukocyte Biology (SLB) members must notify the journal via e-mail (mhayden@faseb.org). If membership information is not provided, authors will be billed at non-member rates.

Within 48 hours, please return your annotated PDF with corrections and comments to the following email address: jlbproduction@faseb.org.

If you have any problems or questions, please contact me. Always include your article no. (2A0312-169) with all correspondence.

The proof contains 11 pages.

Sincerely,

Mary Kiorpes Hayden

FASEB Office of Publications

9650 Rockville Pike

Bethesda, MD 20814-3998

phone: 301-634-7151

fax: 1-240-407-4430

mhayden@faseb.org 
NOTE: Proofs retained by the author for an excessive length of time run the risk of not being published in the issue scheduled. 


\section{INSTRUCTIONS ON THE ANNOTATION OF PDF FILES}

To view, print and annotate your article you will need Adobe Reader version 7 (or higher). This program is freely available for a whole series of platforms that include PC, Mac, and UNIX and can be downloaded from http://www.adobe.com/products/acrobat/readstep2.html. The exact system requirements are given at the Adobe site: http://www.adobe.com/products/reader/systemreqs.

\section{PDF ANNOTATIONS (for this you will need Adobe Reader version 7 or 8; to use version 9 see below)}

To make annotations in the PDF file, go to the main Adobe toolbar and change the cursor from a hand symbol to the normal cursor by clicking on the 'Select' button I Select in the menu bar at the top. When you open the PDF file using Adobe Reader, the Commenting toolbar should be displayed automatically; if not, click on 'Tools', select 'Commenting' (or 'Comment \& Markup'), then click on 'Commenting toolbar' (or Show Comment \& Markup toolbar in Acrobat Reader 8, or Show Commenting bar on the Mac). If these options are not available in your Adobe Reader menus then it is possible that your Adobe version is lower than version 7 or the PDF has not been prepared properly.

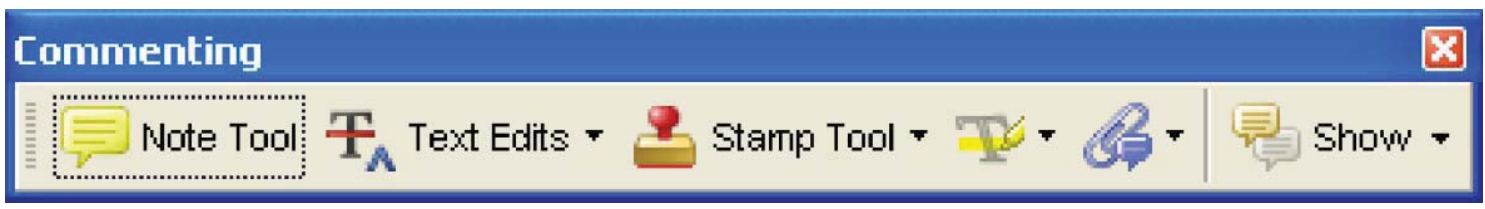

(PC, Adobe version 7)

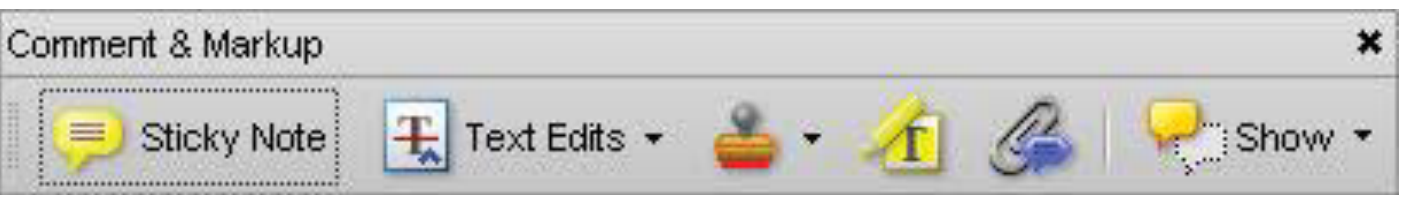

(PC, Adobe version 8, right-click on title bar (Comment \& Markup) to show additional icons)

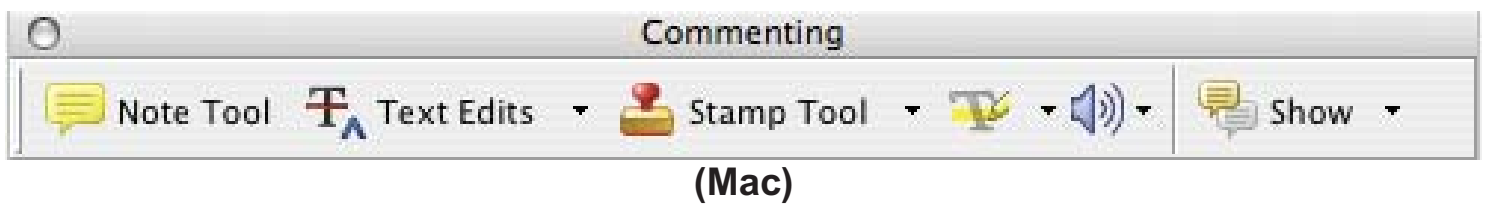

\section{PDF ANNOTATIONS (Adobe Reader version 9)}

The default for the Commenting toolbar is set to 'off' in version 9. To change this setting select 'Edit | Preferences', then 'Documents' (at left under 'Categories'), then select the option 'Never' for 'PDF/A View Mode' - see next page (the Commenting toolbar is the same as in version 8). 


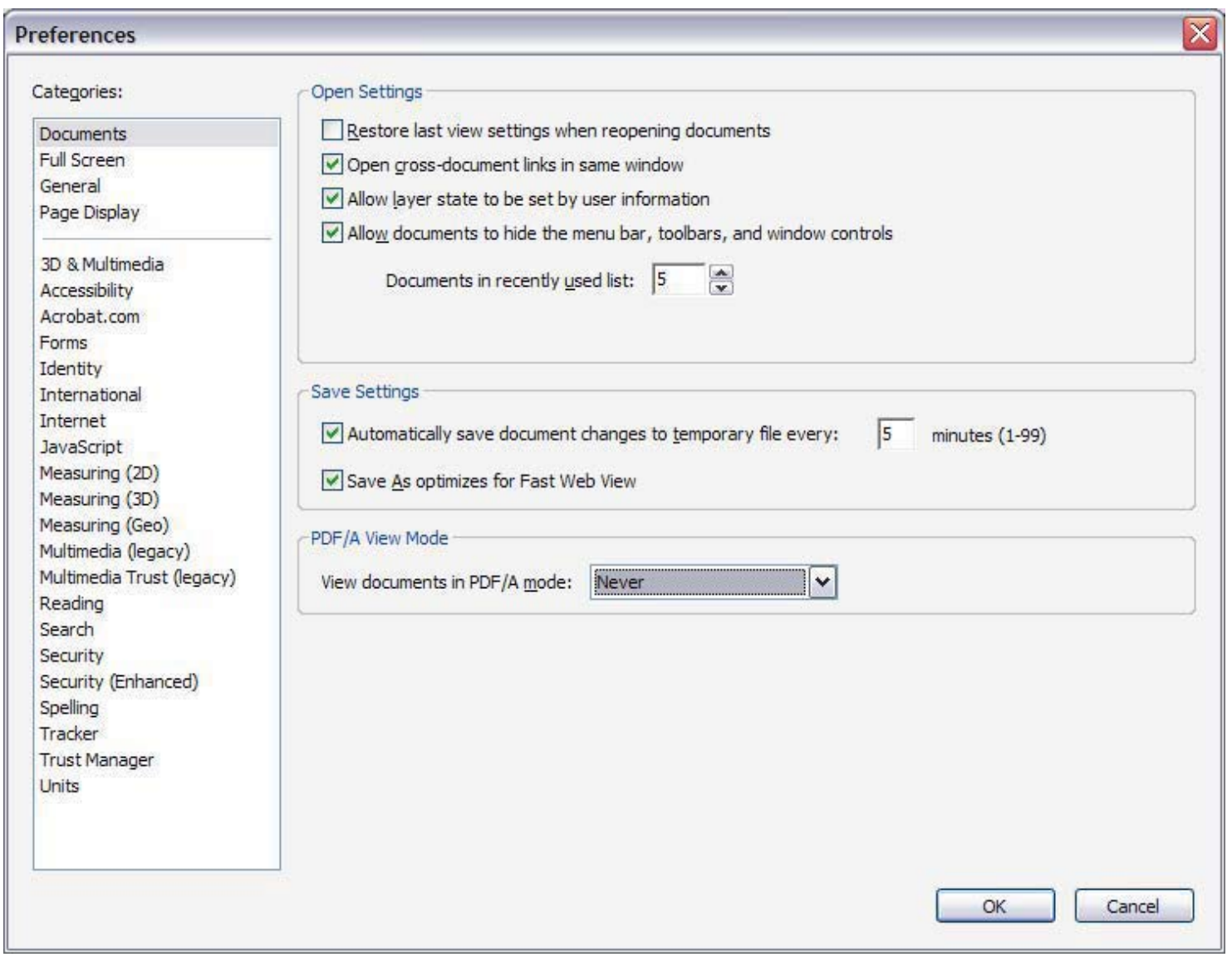

(Changing the default setting, Adobe version 9)

\section{PLEASE DO NOT ATTEMPT TO EDIT THE ARTICLE TEXT ITSELF}

\section{TO INDICATE INSERT, REPLACE, OR REMOVE TEXT}

- Insert text

Click the 'Text Edits' button $\mathrm{F}_{\mathbf{\Lambda}}$ Text Edits - on the Commenting toolbar. Click to set the cursor location in the text and simply start typing. The text will appear in a commenting box. You may also cut-and-paste text from another file into the commenting box. Close the box by clicking on ' $\mathrm{x}$ ' in the top right-hand corner. It can be deleted by right clicking (for the PC, ctrl-click on the Mac) on it and selecting 'Delete'.

\section{- Replace text}

Click the 'Text Edits' button $\mathrm{F}_{\Lambda}$ Text Edits - on the Commenting toolbar. To highlight the text to be replaced, click and drag the cursor over the text. Then simply type in the replacement text. The replacement text will appear in a commenting box. You may also cut-and-paste text from another file into this box. To replace formatted text (an equation for example) please Attach a file (see below).

- Remove text

Click the 'Text Edits' button $\mathrm{F}_{\Lambda}$ Text Edits - on the Commenting toolbar. Click and drag over the text to be deleted. Then press the delete button on your keyboard. The text to be deleted will then be struck through. 


\section{HIGHLIGHT TEXT / MAKE A COMMENT}

Click on the 'Highlight' button
double click on the highlighted text and simply start typing.

\section{ATTACH A FILE}

Click on the 'Attach a File' button on the Commenting toolbar. Click on the figure, table or formatted text to be replaced. A window will automatically open allowing you to attach the file. To make a comment, go to 'General' and then 'Description' in the 'Properties' window. A graphic will appear indicating the insertion of a file.

\section{LEAVE A NOTE / COMMENT}

Click on the 'Note Tool' button Note Tool on the Commenting toolbar. Click to set the location of the note on the document and simply start typing. Do not use this feature to make text edits.

\section{REVIEW}

To review your changes, click on the 'Show' button Show Comments List'. Navigate by clicking on a correction in the list. Alternatively, double click on any mark-up to open the commenting box.

\section{UNDO / DELETE CHANGE}

To undo any changes made, use the right click button on your mouse (for PCs, Ctrl-Click for the Mac). Alternatively click on 'Edit' in the main Adobe menu and then 'Undo'. You can also delete edits using the right click (Ctrl-click on the Mac) and selecting 'Delete'.

\section{SEND YOUR ANNOTATED PDF FILE BACK TO THE JOURNAL PRODUCTION MANAGER VIA jrnlprod.jlb@cenveo.com}

Save the annotations to your file and return as an e-mail attachment using the 'reply' button to the original mail. Before returning, please ensure you have answered any questions raised on the Query form and that you have inserted all corrections: later inclusion of any subsequent corrections cannot be guaranteed.

Note: Comprehensive instructions are provided within your PDF file: to access these instructions please click on the Comments and Markup menu in the main tool bar, or click on Help.

\section{FURTHER POINTS}

- Any (grey) halftones (photographs, micrographs, etc.) are best viewed on screen, for which they are optimized, and your local printer may not be able to output the greys correctly.

- If the PDF files contain colour images, and if you do have a local colour printer available, then it will be likely that you will not be able to correctly reproduce the colours on it, as local variations can occur.

- If you print the PDF file attached, and notice some 'non-standard' output, please check if the problem is also present on screen. If the correct printer driver for your printer is not installed on your PC, the printed output will be distorted. 


\section{AUTHOR INSTRUCTIONS Calculating Publication Costs}

The Journal of Leukocyte Biology now uses an online bill pay system for publication and reprint order fees. The corresponding author will receive a separate e-mail containing a link to a web page where charges can be paid by credit card. The e-mail link also will provide information about invoices, check payment, and wire transfers.

Publication charges are calculated based on the final version of the article-not this proof. Color figures have the word "COLOR" in the margins. Grayscale (black and white) figures have no tag. If you wish to change a color figure to grayscale, cross out the word "color" and write in "grayscale." Please note that figures are published the same way in the online and print versions of the journal. Authors may not publish figures in color online while publishing the same figures in grayscale in print or vice-versa.

For your convenience and records, the following table should help you estimate publication charges. Please account for any changes you have made to your proofs. Please do not fax this sheet to the editorial office. Your charges will be calculated automatically based on the final article.

TO ENSURE THAT AUTHORS ARE BILLED PROPERLY, SOCIETY OF LEUKOCYTE BIOLOGY (SLB) MEMBERS MUST E-MAIL A MESSAGE STATING WHICH AUTHOR IS A MEMBER TO MARY KIORPES-HAYDEN AT MHAYDEN@FASEB.ORG WHEN THEY SUBMIT THEIR PROOF CORRECTIONS. PLEASE NOTE SLB PROOF CORRECTIONS MUST BE SENT TO A DIFFERENT ADDRESS: jrnlprod.jlb@cenveo.com. If authors do not e-mail Ms. Kiorpes-Hayden, they will be billed at non-member rates.

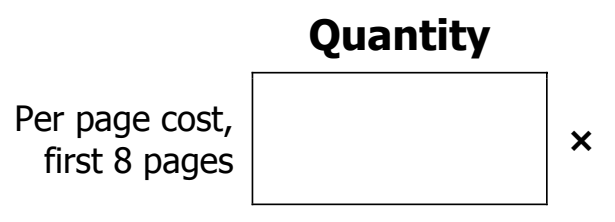

Per page cost, $9^{\text {th }}$ page and beyond Color figure charge, $1^{\text {st }}$ page
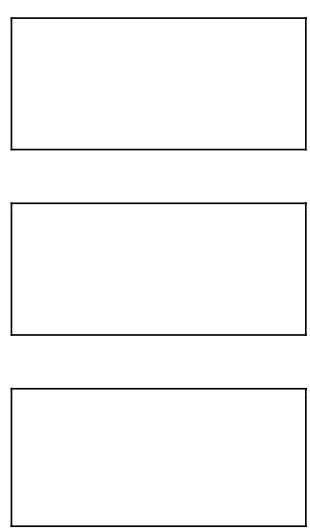

charge, $2^{\text {nd }}$ page and beyond

Supplemental files? If yes, then enter the quantity (maximum of four units). If no, then enter 0 .

$\times$

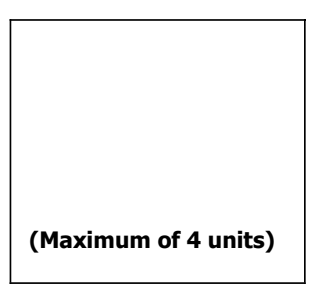

$\$ 90$ per page (SLB member) $\$ 120$ per page (non-SLB member)

$\$ 45$ per page (SLB member) $\$ 60$ per page (non-SLB member)

(1)
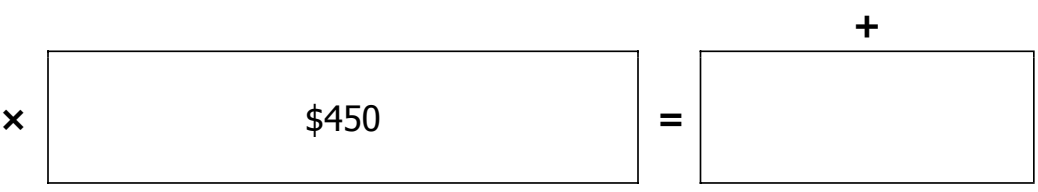

$+$
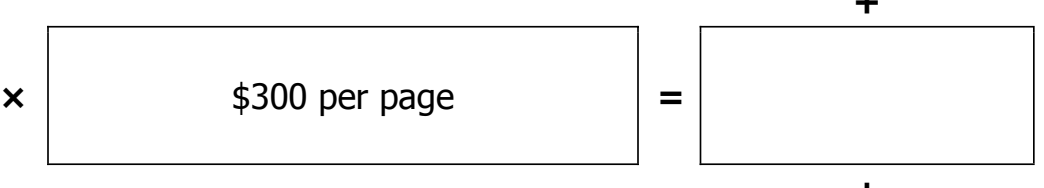

$+$

\section{Total Publication Charges:}

This sheet is for estimation purposes only. Final costs are calculated using the final printed version of the article. All prices are in U.S. Dollars. Reprints can be purchased when paying publication charges online. 


\title{
Mandatory Submission and Copyright Transfer Form
}

\author{
Manuscript Number: 2A0312-169
}

Title: B cell receptor-induced $\mathbf{C a}$ + mobilization mediates $\mathbf{F}$-actin rearrangements and is indispensable for adhesion and spreading of B tymphreytes

\section{Signatures Below Certify Compliance with the Following Statements}

Copyright transfer. In consideration of the acceptance of the above work for publication, I do herby assign and transfer to the Society for Leukocyte Biology (SLB) all rights, titles, and interest in and to the copyright in the Journal of Leukocyte Biology. This includes preliminary display/posting of the abstract of the accepted article in electronic form before publication. The journal grants the author permission to provide a copy of the accepted manuscript to NIH upon acceptance for Journal publication, with public release in PubMed Central twelve months after final print publication by the Journal of Leukocyte Biology.

This form must be signed by all authors. If any changes in authorship (order, deletions, or additions) occur after the manuscript is submitted, agreement by all authors for such changes must be on file with SLB. An author's name may only be removed at his/her own request and with written consent from all of the other authors, as well as final approval by the Editor-in-Chief. Material prepared by employees of the US Government in the course of their official duties cannot be copyrighted; work prepared by employees of the British or British Commonwealth government in the course of their official duties is subject to Crown Copyright and cannot be transferred to SLB. Nevertheless, authors must sign the form to indicate acceptance of all terms other than copyright transfer.

O Please check if this article was written as part of the official duties of an employee of the United States government.

O Please check if this article was written as part of the official duties of an employee of the British or British Commonwealth government.

Authorship responsibilities. I attest that:

1. the manuscript is not currently under consideration, in press, or published elsewhere, and the research reported will not be submitted for publication elsewhere until a final decision has been made as to its acceptability by the Journal of Leukocyte Biology (posting of submitted material on a website or by any other electronic means may be considered prior publication-note this in your cover letter);

2. the manuscript is truthful, original work without fabrication, fraud, or plagiarism;

3. I have made an important scientific contribution to the study and am thoroughly familiar with the primary data and;

4. I have read the complete manuscript and take responsibility for the content and completeness of the manuscript and understand that I share responsibility if the paper, or part of the paper, is found to be faulty or fraudulent.

Conflict of Interest Disclosure. All funding sources supporting the work and all institutional or corporate affiliations of mine are acknowledged. Except as disclosed on a separate attachment, I certify that I have no commercial associations (e.g., consultancies, stock ownership, equity interests, patent-licensing arrangements, etc.) that might pose a conflict of interest in connection with the submitted article, and that I accept full responsibility for the conduct of the trial, had full access to all the data, and controlled the decision to publish.

Author Fees. I agree to pay pages charges and applicable color fees. (Page charges for non-SLB members are $\$ 60$ per page for the first 8 printed pages and $\$ 120$ per page for the 9th page and beyond. Page charges for SLB members are $\$ 45$ per page for the first 8 printed pages and $\$ 90$ per page for the 9th page and beyond. The color charge is $\$ 450$ for the first page of color and $\$ 300$ each for additional pages of color. Supplemental data are $\$ 125$ per unit, maximum of four units.)

Author Signatures. For more than 10 authors, use an extra sheet. Multiple forms are acceptable.

Signature (1) Print Name Date

Signature (2) Print Name Date

Signature (3) Print Name Date

Signature (4) Print Name Date

Signature (5) Print Name Date

Signature (6) Print Name Date

Signed forms should be faxed to 301-634-7809 or scanned and emailed to mhayden@faseb.org. Signed forms can also be mailed to Journal of Leukocyte Biology, Office of Publications, 9650 Rockville Pike, Bethesda, MD 20814-3998. 


\title{
$\mathrm{B}$ cell receptor-induced $\mathrm{Ca}^{2+}$ mobilization mediates F-actin rearrangements and is indispensable for adhesion and spreading of B lymphocytes
}

\author{
Máté Maus, * David Medgyesi, ${ }^{\dagger}$ Endre Kiss, * Andrea E. Schneider,* Ágnes Enyedi, ${ }^{\ddagger}$ \\ Nóra Szilágyi, ${ }^{\S}$ János Matkó,* and Gabriella Sármay*,1 \\ Departments of *Immunology and ${ }^{\$}$ Physiology and Neurobiology, Eötvös Lóránd University, Budapest, Hungary; ${ }^{\dagger}$ Department \\ of Molecular Immunology, Max Planck Institute of Immunology, Freiburg, Germany; and ${ }^{\ddagger}$ Department of Molecular Cell \\ Biology, National Blood Center, Budapest, Hungary
}

RECEIVED MARCH 30, 2012; REVISED JANUARY 10, 2013; ACCEPTED JANUARY 11, 2013. DOI: 10.1189/jlb.0312169

\begin{abstract}
$B$ cells acquire membrane-bound cognate antigens from the surface of the APCs by forming an IS, similar to that seen in T cells. Recognition of membrane-bound antigens on the APCs initiates adhesion of B lymphocytes to the antigen-tethered surface, which is followed by the formation of radial lamellipodia-like structures, a process known as B cell spreading. The spreading response requires the rearrangement of the submembrane actin cytoskeleton and is regulated mainly via signals transmitted by the BCR. Here, we show that cytoplasmic calcium is a regulator of actin cytoskeleton dynamics in B lymphocytes. We find that BCR-induced calcium mobilization is indispensible for adhesion and spreading of B cells and that PLC $\gamma$ and CRAC-mediated calcium mobilization are critical regulators of these processes. Measuring calcium and actin dynamics in live cells, we found that a generation of actin-based membrane protrusion is strongly linked to the dynamics of a cytoplasmic-free calcium level. Finally, we demonstrate that PLC $\gamma$ and CRAC channels regulate the activity of actin-severing protein cofilin, linking BCR-induced calcium signaling to the actin dynamics. J. Leukoc. Biol. 93: 000-000; 2013.
\end{abstract}

\section{Introduction}

B lymphocytes mediate humoral immunity by recognizing foreign antigens and producing antigen-specific antibodies

\footnotetext{
Abbreviations: 2-APB =2-aminoethoxydiphenyl borate, Arp2/3=actin-related protein 2/3, Blnk=B cell linker, Btk=Bruton's tyrosine kinase, CLSM=confocal laser-scanning microscope, $C R A C=$ calcium release-activated calcium channel, IS=immunological synapse, $\mathrm{NMI}=$ normalized $\mathrm{mu}$ tual information, p-cofilin=phosphorylated cofilin, Ser $3=$ serine 3 , $\mathrm{SOCE}=$ store-operated calcium entry, WASP $=$ Wiskott-Aldrich syndrome protein
}

The online version of this paper, found at unw.jleukbio.org, includes supplemental information. against them. After their generation in the bone marrow, naive B cells migrate to the secondary lymphoid tissues to encounter antigen. Here, they gain direct access to small, diffusible antigens, whereas larger antigens are presented to them on the surface of APCs, such as DCs [1].

Recognition of membrane-tethered antigens initiates a process known as B cell spreading. B cells spread over the antigen-coated surface of the APCs by forming lamellopodial membrane protrusions in parallel with an intracellular calcium response [2]. This process leads to the formation of an IS between the APC and B cell [3], similar to that seen between APCs and T cells [4-6]. The spreading response is dependent on the affinity and density of the antigen [2] and requires the reorganization of the actin cytoskeleton [7-10].

Cell spreading relies on an outward force on the plasma membrane that is exerted by the formation of branched F-actin networks at the contact area. Formation of such networks requires the disruption of pre-existing long filaments by actinsevering proteins, such as cofilin, and the initiation of filament branching via binding of the activated Arp2/3 complex to the filaments. The Rap and Rac2 GTPases have been implicated to play a role in both processes and to be required for $\mathrm{B}$ cell spreading $[11,12]$. The GTP-bound form of Rap1 is an upstream regulator of Vav2, a guanine-nucleotide exchanger protein that promotes actin polimeryzation and branching via activating the WASP family Verprolin-homologous protein/WASP pathway [13]. Rap also plays a role in the activation of cofilin. The actin-severing protein cofilin was shown to be essential for F-actin severing and cytoskeletal rearrangement that underlie B cell spreading [12].

Weber et al. [7] have implicated the importance of another pathway in B cell spreading that includes PLC $\gamma \gamma 2$, the Btk, and the Blnk. In B cells, PLC $\gamma$ is the main regulator of BCR-

1. Correspondence: Dept. of Immunology, Eötvös Lóránd University, Pázmány Péter sétány 1/c, 1117 Budapest, Hungary. E-mail: sarmayg@elte.hu 
driven cytoplasmic $\mathrm{Ca}^{2+}$ mobilization. PLC $\gamma$ gets phosphorylated by the Blnk/Btk complex $[14,15]$ to produce inositol1,4,5-trisphosphate, a second messenger that rapidly releases $\mathrm{Ca}^{2+}$ from the ER [16]. Depletion of the ER Ca ${ }^{2+}$ stores is followed by the opening of plasma membrane CRAC channels [17], allowing $\mathrm{Ca}^{2+}$ influx from the extracellular space, a process that is known as SOCE [18], which is the main mechanism to provide a sustained increase in the cytoplasmic calcium in lymphocytes [19].

There are several pieces of evidence implicating that cytoplasmic $\mathrm{Ca}^{2+}$ may regulate actin rearrangements in several cell types [20-22]. A number of actin-binding proteins are sensitive to changes in the cytoplasmic calcium concentration: actin-severing protein gelsolin can induce gel-sol transition of the cytoplasm by calcium-dependent severing of actin filaments [23], and actin-bundling protein $\alpha$-actinin is inhibited in a $\mathrm{Ca}^{2+}$-dependent manner [24].

The effect of calcium on the structure of actin cytoskeleton is supported by measurements of localization and amount of F-actin after experimentally induced calcium transients. Most of the studies support that elevations in cell calcium have a specific, destructive effect on the cortical actin cytoskeleton [20-22].

Taken the importance of PLC $\gamma$ in B cell spreading and the implications for a role of cytoplasmic $\mathrm{Ca}^{2+}$ in actin rearrangements, we tested the hypothesis that BCR-driven cytoplasmic $\mathrm{Ca}^{2+}$ mobilization can regulate actin rearrangements and is required for B cell spreading. We show that PLC $\gamma$ and CRAC channel function is crucial for adhesion and spreading of $\mathrm{B}$ cells to antigen-tethered surfaces. The level of cytoplasmic $\mathrm{Ca}^{2+}$ regulates F-actin rearrangements. Furthermore, we show in live cells that the generation and disruption of actin-based membrane protrusions are linked to the level of cytoplasmicfree $\mathrm{Ca}^{2+}$. We find that the activity of actin -severing protein cofilin depends directly on PLC $\gamma$ and CRAC channel activity, linking BCR-induced cytoplasmic $\mathrm{Ca}^{2+}$ mobilization to actin cytoskeleton reorganization and B cell spreading.

\section{MATERIALS AND METHODS}

\section{Reagents and antibodies}

Antibodies used in our experiments were anti-p-cofilin, anti-Cofilin, and anti-actin (Sigma-Aldrich, Budapest, Hungary) and Alexa647-conjugated anti-rabbit IgG (Invitrogen, Carlsbad, CA, USA). Rabbit anti-mouse IgG and rabbit $\mathrm{F}\left(\mathrm{ab}^{\prime}\right)_{2}$ anti-mouse IgG (Jackson ImmunoResearch Laboratories, West Grove, PA, USA) were used for the stimulation of A20 cells. Alexa488conjugated phalloidin (Invitrogen) was used for F-actin staining. Fluo-4 AM (Invitrogen) was used for calcium imaging. CellTracker Green (Invitrogen) was used for staining B cells for the spreading measurements. Ionomycin calcium salt from Streptomyces conglobatus (\#I0634), EGTA (E-4378), and latrunculin B were purchased from Sigma-Aldrich. Peroxidase-labeled antibodies were detected using the Pierce (Budapest, Hungary) ECL reagent. CRAC inhibitor 2-APB and PLC $\gamma$ inhibitor U73122 were purchased from Sigma-Aldrich. Actin-stabilizing drug Jasplakinolide was purchased from Enzo Life Sciences (Butler Pike, PA, USA).

\section{Cells}

A20 (ATCC TIB208, I-Ad/Ed+) cells are murine B cell lymphomas and often used as a model of mature murine B cells. A20 cells were cultured in
RPMI 1640, supplemented with $2 \mathrm{mM}$ L-glutamine, $1 \mathrm{mM}$ Na-pyruvate, 50 $\mu \mathrm{M}$ 2-ME, antibiotics, and $10 \%$ FCS. Cells were kept at $37^{\circ} \mathrm{C}, 5 \% \mathrm{CO}_{2}$ in a humidified atmosphere.

Murine primary B lymphocytes were isolated from the spleen of adult (6-8 weeks old) female BALB/c mice by negative selection. After lyses of the red blood cells, cells were washed and treated with anti-Thy-1.2 antibody for $30 \mathrm{~min}$ at room temperature and washed once more. The cell suspension was incubated further with RPMI-1640 medium containing rabbit complement for $30 \mathrm{~min}$ at $37^{\circ} \mathrm{C}$. The percentage of $\mathrm{B}$ cells was analyzed by flow cytometry using fluorescently labeled anti-B220 and anti-CD3 antibodies and was found $>90 \%$ in every case.

\section{Constructs}

mCherry-actin was cloned between BamHI and EcoRI sites of the retroviral expression vector pMOWS that contains a puromycin resistance gene for selection [25]. mCherry was amplified with the primers gattggatccgccaccatggtgagcaagggcgag and cctgcatatgacccttgtacagctcgtccat using as a template the pMIG-mCherry plasmid (kindly provided by Hassan Jumaa, Max Planck Institute of Immunobiology and Epigenetics, Freiburg, Germany). $\beta$-Actin was amplified with the primers ggtcatatgggaatggatgacgatatcgctg and cttagaattcctagaagcacttgcggtgcac. The insertion was done sequentially using the NdeI site built in the relevant primers.

\section{Retroviral transfection}

A20 cells were retrovirally transduced as described previously [26]. Briefly, the Phoenix retroviral producer cell line was transfected using GeneJuice (Novagen), according to the manufacturer's instructions. Retroviral supernatants were harvested after 36 and $60 \mathrm{~h}$ post-transfection. Cells $\left(2 \times 10^{5}\right)$ were mixed with $500 \mu$ retroviral supernatant and centrifuged at $300 \mathrm{~g}$ at $37^{\circ} \mathrm{C}$ for $3 \mathrm{~h}$. Transduced cells were cultured in RPMI medium. Puromycin $(10 \mu \mathrm{g} / \mathrm{ml})$ was added to the culture medium $24 \mathrm{~h}$ later. Three days later, positive cells were sorted using a Beckman Coulter (Nyon, Switzerland) MoFlo cell sorter.

\section{Confocal microscopy}

For single-cell calcium imaging, A20 was grown on eight-well chambered Lab-Tek borosilicate coverglasses (Nunc, Rochester, NY, USA; $4 \times 10^{4}$ cells/chamber well). After $12 \mathrm{~h}$ in culture, cells were washed and incubated for $15 \mathrm{~min}$ at $37^{\circ} \mathrm{C}$ in $10 \mu \mathrm{g} / \mathrm{ml}$ Fluo- $4 \mathrm{AM}$ solution prepared in RPMI-1640 medium (Sigma-Aldrich). After loading, samples were washed four times. Images were taken with a Fluoview 500 (Olympus, Hamburg, Germany) CLSM using an average time resolution of 1.375 $\mathrm{s} /$ frame. An Ar-ion laser (488 nm) was used for the excitation of Fluo-4 fluorescence, which was detected through a band-pass filter $520 \pm 20$ $\mathrm{nm}$. EGTA was used in $2 \mathrm{mM}$ or in $20 \mathrm{mM}$ for inducing cytoplasmic $\mathrm{Ca}^{2+}$ oscillations in mCherry-actin-expressing A20 cells, ionomycin in 2 $\mu \mathrm{g} / \mathrm{ml}$ concentration.

B cell spreading was also analyzed by CLSM in Lab-Tek microplates coated with mouse-specific anti-IgM or $-\operatorname{IgG}(10 \mu \mathrm{g} / \mathrm{ml})$. After $60 \mathrm{~min}$, microplates at $37^{\circ} \mathrm{C}$ incubation were washed three times with carbonate buffer. Then, microplates were further coated with BSA $(1 \mathrm{mg} / \mathrm{ml})$ for $30 \mathrm{~min}$ at $37^{\circ} \mathrm{C}$. A20 or spleen B cell suspensions at $2 \times 10^{5}$ density were pretreated occasionally with $2.5 \mu \mathrm{M}$ U73122 or $100 \mu \mathrm{M}$ 2-APB for $5 \mathrm{~min}$ at $37^{\circ} \mathrm{C}$ before the spreading. After pretreatment, cells were pipetted into the wells for 2, 4, 6, or $8 \mathrm{~min}$ and then fixed with $2 \%$ PFA $\left(5 \mathrm{~min}, 37^{\circ} \mathrm{C}\right)$. After the spreading and fixation, microplates were washed twice with PBS. The adhered cells were stained with $66 \mathrm{nM}$ phalloidin Alexa488 for $5 \mathrm{~min}$ at $37^{\circ} \mathrm{C}$ and then washed four times with PBS. The contact surfaces of the cells were monitored in CLSM (excitation: $488 \mathrm{~nm}$ ). The contact zone area was determined using ImageJ software (http://rsbweb.nih.gov/ij).

\section{Calcium measurement by flow cytometry}

A20 cells were washed and incubated for $15 \mathrm{~min}$ at $37^{\circ} \mathrm{C}$ in $10 \mu \mathrm{g} / \mathrm{ml}$ Fluo-4 AM solution, prepared in RPMI-1640 medium (Sigma-Aldrich). 
After loading, samples were washed and resuspended in RPMI 1640. Ionomycin $(2 \mu \mathrm{g} / \mathrm{ml})$ was used to raise or $2 \mathrm{mM}$ EGTA to lower the cytoplasmic-free calcium level. Fluorescence measurements were performed using FACSCalibur or FACSAria III (Becton Dickinson, Mountain View, CA, USA) flow cytometers using an air-cooled argon ion laser (488 $\mathrm{nm}$ excitation) and red diode laser (632 nm excitation). Data collection and analysis were done with CellQuest Pro and DIVA software. During data analysis, dead cells were excluded by negative gating based on PI uptake.

\section{Measurement of F-actin level by flow cytometry}

A20 cells $\left(5 \times 10^{5} /\right.$ tube) were collected in $300 \mu \mathrm{l}$ RPMI 1640 and treated at $37^{\circ} \mathrm{C}$ with $2 \mu \mathrm{g} / \mathrm{ml}$ ionomycin, $2 \mathrm{mM}$ EGTA, or both for time intervals as indicated. Immediately after treatment, $100 \mu \mathrm{l}$ of a solution containing $10 \%$ PFA, $0.05 \%$ Triton-X, and $66 \mathrm{nM}$ Alexa488-conjugated phalloidin was mixed to the samples. After labeling on ice for $10 \mathrm{~min}$, samples were washed carefully and analyzed quantitatively on a FACSAria III (Becton Dickinson) flow cytometer.

\section{Immunofluorescence}

After stimulation on an eight-well chamber, cells were fixed in 3\% PFA for $5 \mathrm{~min}$ at $37^{\circ} \mathrm{C}$, then incubated at $4^{\circ} \mathrm{C}$ for $10 \mathrm{~min}$, washed two times with RPMI 1640, and permeabilized in $0.1 \%$ Triton X-100 (Sigma-Aldrich) at room temperature for $5 \mathrm{~min}$. After a triple washing with PBS, cells were stained with Alexa448-conjugated phalloidin and in the case of primary B cells, with rabbit anti-cofilin antibody. Alexa647-conjugated anti-rabbit IgG was used in a concentration provided by the manufacturer.

\section{Stimulation of primary B cells with anti-IgM and preparation of cell lysates}

Cells $\left(2 \times 10^{6}\right) /$ sample were stimulated with $5 \mu \mathrm{g} / \mathrm{ml}$ mouse-specific antiIgM antibody (rabbit) at $37^{\circ} \mathrm{C}$ for 0,2 , and $5 \mathrm{~min}$, respectively. Cells were pelleted for $20 \mathrm{~s}$ and frozen immediately in liquid nitrogen. For lysis of the cells, cells were solubilized in $20 \mu \mathrm{l}$ lysis buffer containing $1 \%$ Triton X-100, $50 \mathrm{mM}$ HEPES (pH 7.4), $100 \mathrm{mM} \mathrm{NaF}, 250 \mathrm{mM} \mathrm{NaCl}, 10 \mathrm{mM}$ EDTA, $2 \mathrm{mM}$ sodium-o-vanadate, $10 \mathrm{mM}$ sodium pyrophosphate, $10 \%$ glycerol, $10 \mu \mathrm{g} / \mathrm{ml}$ aprotinin, $10 \mu \mathrm{g} / \mathrm{ml}$ pepstatin, $5 \mu \mathrm{g} / \mathrm{ml}$ leupeptin, and 0.2 $\mathrm{mM}$ PMSF. After $30 \mathrm{~min}$ of incubation on ice, cell lysates were centrifuged at $15,000 \mathrm{~g}$ for $15 \mathrm{~min}$ at $4^{\circ} \mathrm{C}$, and the supernatants were collected for subsequent experiments.

\section{Immunoblotting}

Samples were subjected to electrophoresis through $15 \%$ SDS-PAGE gel, and the proteins were blotted onto nitrocellulose membranes (Bio-Rad, Budapest), probed with the appropriate antibodies, and developed by HRP-conjugated anti-rabbit IgG, followed by ECL detection (Amersham).

\section{Measurement of B cell adhesion-spreading response}

Ninety-six-well flat-bottom ELISA plates were coated with mouse-specific anti- $\operatorname{IgM}$ or $-\operatorname{IgG}(2 \mu \mathrm{g} / \mathrm{ml})$. After $30 \mathrm{~min}$ incubation at $37^{\circ} \mathrm{C}$ and 90 min at room temperature, ELISA plates were washed several times. After washing, plates were coated further with BSA $(3 \mathrm{mg} / \mathrm{ml})$ for an additional $60 \mathrm{~min}$. A $100-\mu \mathrm{l}$ cell suspension $\left(5 \times 10^{5} \mathrm{cells} / \mathrm{ml}\right)$ was pipetted into each well that was used in the experiment. Cells in the suspension were stained previously with CellTracker Green (Invitrogen), according to the instructions of the manufacturer. If indicated, cells were treated with U73122 $(2.5 \mu \mathrm{M})$ or with 2-APB $(100 \mu \mathrm{M})$ for 5 min or with Jasplakinolide for $30 \mathrm{~min}$ before subjecting them to the plate. Cells were incubated on the ELISA plate at $37^{\circ} \mathrm{C}, 5 \% \mathrm{CO}_{2}$, in a humidified atmosphere for a certain time indicated in the case of every experiment, then fixed, and washed four times. To determine the amount of stably adhered and spreaded cells to the surface, fluorescence was measured in a Fluoroskan Ascent FL (Thermo Scientific, Waltham, MA, USA) fluorescent ELISA microplate reader.

\section{Calculation of cell roundness and Mander's coefficients}

Roundness of cells was defined as $4 \times$ (area of the cell $) /(\pi \times$ major axis of the cell) and was calculated by initially determining the outline of individual cells in every frame with the Dynamic threshold plug-in of Image $\mathrm{J}$ software based on the fluorescent image. Roundness defined as above was then calculated using the Shape Descriptor ImageJ plug-in [27].

For calculation of Mander's colocalization coefficients [28], Image correlation analysis was performed in Image J after background subtraction [28].

\section{Statistical methods}

For testing the differences between the experimental interdependence of cytoplasmic $\mathrm{Ca}^{2+}$ and cortical mCherry-actin signal and surrogate data, the Neyman's smooth statistic was applied (for further details, see the next section). Unpaired Student's $t$-test was applied to test for statistical differences between datasets in all other experiments.

\section{Mathematical/statistical analysis of dynamic interdependence of cytoplasmic-free $\mathrm{Ca}^{2+}$ and cortical F-actin levels}

Data for calculating the interdependence of cytoplasmic $\mathrm{Ca}^{2+}$ and cortical actin were obtained by CLSM imaging of A20 cells expressing the fusion protein mCherry-actin. Cells were loaded with the $\mathrm{Ca}^{2+}$ indicator Fluo-4, and oscillations were evoked by EGTA $(20 \mathrm{mM})$. Numeric values of the amount of cortical actin and cytoplasmic level of free $\mathrm{Ca}^{2+}$ were obtained from individual images by defining a region of interest around the plasma membrane from frame to frame manually. Experimental data were obtained from four different measurements.

As $\mathrm{Ca}^{2+}$ and cortical actin signals were contaminated by measurement noise, smoothing spline was applied as preprocessing. Very low frequency oscillations were eliminated using trend removal procedures. Instantaneous phases were calculated by Hilbert transform [61]. To detect and quantify synchronization, an entropy-based synchronization index, the NMI, was calculated (also known as symmetric uncertainty).

To detect and quantify synchronization for the two variables, an entropybased synchronization index, the mutual information $(I)$ was calculated as follows

$$
I(X ; Y)=\sum_{\mathrm{y} \in Y} \sum_{x \in X} p(x, y) \log \left(\frac{p(x, y)}{p_{I}(x) p_{2}(y)}\right),
$$

where $p(x, y)$ is the joint probability distribution function of cytoplasmic level of free $\mathrm{Ca}^{2+}(x)$ and the amount of cortical actin $(y)$, and $p(x)$ and $p(y)$ are the marginal probability density functions of the two variables.

NMI was obtained by normalization of $I(X ; Y)$ by $H(X)+H(Y)$, the sum of marginal entropies.

NMI has important advantages over other synchronicity measures-most of all, its ability to grasp nonlinear interdependence (beyond linear dependency) and provide a general characterization of all possible frequency locking [62]. As a result of the normalization, the value of NMI falls in the range $[0,1]$. To expose the dynamics of the mutual interaction between the $\mathrm{Ca}^{2+}$ and cortical actin signals, windowed ("running") entropies were estimated within 15 consecutive, nonoverlapping windows of 52-s lengths.

For statistical comparisons, "fully synchronized" and "asynchronous" surrogates were generated under two null hypotheses, proposing that the data show both extremes-the possible lowest and highest synchronization. Asynchronous surrogates were created by shuffling of the original phases using permutation. Fully synchronized surrogates were the realizations of experimental data reproduced with identical phases. For testing the differences between the experimental and surrogate data, the Neyman's smooth statistics [63] was used, making it data driven by applying the Schwarz's 
selection rule. Mathematical calculations were accomplished with Matlab 6.5 software environment (MathWorks, Natick, MA, USA) by the application of self-devised scripts for preprocessing, entropy measures, surrogate analysis, and adaptive Neyman's tests.

\section{RESULTS}

\section{BCR-induced calcium mobilization is a prerequisite for $B$ cell adhesion/spreading}

To understand the role of BCR-mediated $\mathrm{Ca}^{2+}$ mobilization in the regulation of $\mathrm{B}$ cell adhesion and spreading, we used the compounds U73122, an inhibitor of PLC $\gamma$, and 2-APB, an inhibitor of CRAC channels, to model complete loss of $\mathrm{Ca}^{2+}$ mobilization or loss of $\mathrm{Ca}^{2+}$ influx only throughout the spreading response. With the use of flow cytometry, we verified that 2-APB $(100 \mu \mathrm{M})$ significantly reduces the peak of cytoplasmic $\mathrm{Ca}^{2+}$ (Fig. 1A and B), whereas inhibiting PLC $\gamma$ by U73122 $(2.5 \mu \mathrm{M})$ fully abolishes $\mathrm{Ca}^{2+}$ mobilization upon BCR stimulation in mouse B lymphoma cell line A20 and in murine splenic B cells (Fig. 1A and B).

We modeled adhesion and spreading of B cells on APCs by incubating A20 cells or murine splenic B cells on surfaces that were previously coated with an anti-Ig antibody. After 2, 4, 6, or $8 \mathrm{~min}$, cells were fixed, and nonadherent cells were removed by washing. To quantify adhesion of cells prior to incubation on the antigen-tethered surfaces, cells were loaded with CellTracker Green. After fixation and washing, the relative number of adherent cells was determined by measuring the fluorescence on the anti-Ig-coated surface. The number of adherent cells showed a time-dependent increase for untreated A20 cells (Fig. 1C) and primary B cells (Fig. 1D). Inhibition of $\mathrm{Ca}^{2+}$ influx by 2-APB markedly reduced the ability of cells to adhere to the antigen surfaces; after $8 \mathrm{~min}$ of incubation, we measured an $\sim 30 \%$ reduction in the relative number of adherent A20 cells (Fig. 1C) and an $\sim 40 \%$ reduction in adherent primary B cells (Fig. 1D) when compared with untreated cells. Inhibition of PLC $\gamma$ by U73122 had a more severe effect, reducing the relative number of stably adhering cells by $\sim 60 \%$ in the case of A20 cells (Fig. 1C) and by $\sim 80 \%$ in the case of primary B cells (Fig. 1D) after $8 \mathrm{~min}$ of incubation.

To investigate how inhibition of BCR-mediated $\mathrm{Ca}^{2+}$ mobilization affects B cell spreading, in particular, cells, able to adhere with or without 2-APB or U73122 treatment, were stained for F-actin with phalloidin-Alexa488, and images of the adhesive area were taken using confocal microscopy. Whereas control A20 and murine splenic B cells once adhering to the antigen surface underwent spreading by forming radial lamellipodia, cells treated with 2-APB or U73122 severely lacked radial lamellipodia formation (Fig. $1 \mathrm{E}$ and $\mathrm{F}$ ). The adhesive area of control cells increased in a time-dependent manner, whereas 2-APB and U73122 treatment almost completely abolished the expansion of the adhesive area (Fig. $1 \mathrm{G}$ and $\mathrm{H}$ ). Based on our results, we concluded that BCR-mediated cytoplasmic $\mathrm{Ca}^{2+}$ mobilization is indispensable for adhesion and spreading of $\mathrm{B}$ cells to antigen-tethered surfaces.

\section{Cytoplasmic level of free $\mathrm{Ca}^{2+}$ regulates $\mathrm{F}$-actin level in $B$ cells}

The shape of lymphocytes is determined primarily by the cortical actin cytoskeleton. Resting lymphocytes have a spherical structure covered by short microvilli, dense bundles of actin filaments enclosed in plasma membrane [29]. BCRs on resting $\mathrm{B}$ cells are trapped into focally localized microclusters by the subplasma membrane actin network [30]. Adhesion and spreading of B cells to the antigen-tethered surface require the remodeling of the actin cytoskeleton and polarization of the BCRs to the contact surface. This may be achieved by an early event of F-actin depolymerization [31] and subsequent rearrangement of the actin structure.

There are several pieces of evidence implicating that cytoplasmic $\mathrm{Ca}^{2+}$ can regulate actin rearrangements [20-22]. We hypothesized that BCR-mediated $\mathrm{Ca}^{2+}$ mobilization is required for the remodeling of the subplasma membrane actin cytoskeleton, thereby limiting B cell adhesion and spreading. To understand how calcium mobilization affects morphology and structure of the actin cytoskeleton of B cells, adherent A20 cells loaded with the fluorescent calcium indicator Fluo-4 were exposed to the calcium ionophor ionomycin [32] and investigated by single-cell confocal imaging. The exposure of cells to ionomycin $(2 \mu \mathrm{g} / \mathrm{ml})$ induced a four- to sixfold increase in the intracellular-free calcium level (Fig. 2A) and was followed by a dramatic transition in cell shape, resulting in loss of protrusive membrane structures and ultimately leading to rounding of cells (Fig. 2A and Supplemental Video 1). The exposure of cells to ionomycin and the $\mathrm{Ca}^{2+}$ chelator EGTA $(2 \mathrm{mM})$ or to EGTA (2 $\mathrm{mM})$ alone had no apparent effect on cell morphology (Fig. 2B and C and Supplemental Videos 2 and 3), suggesting that rounding of cells upon ionomycin exposure was mediated by the $\mathrm{Ca}^{2+}$ influx.

We quantified the morphological transition upon $\mathrm{Ca}^{2+}$ influx by measuring roundness of individual cells before and after the treatment. Initial roundness of cells treated with ionomycin, ionomycin + EGTA, or EGTA alone was statistically not different (Fig. 2D). Twelve minutes of ionomycin treatment induced an $\sim 25 \%$ increase in the roundness of cells, whereas ionomycin + EGTA or EGTA alone had no statistically significant effect on roundness of cells (Fig. 2E).

Staining cells with phalloidin-Alexa488, a fungal toxin specifically binding filamentary actin, revealed the that ionomycininduced $\mathrm{Ca}^{2+}$ influx had a specific disruptive effect on the cortical actin cytoskeleton. Whereas cells exposed to EGTA or ionomycin + EGTA showed an actin structure similar to control cells with F-actin-rich lamellipodia and membrane ruffles, cells exposed to ionomycin lacked all kinds of peripheral-protrusive actin structures, indicating a rearrangement of the cortical actin network (Fig. 2F).

To investigate further how $\mathrm{Ca}^{2+}$ influx leads to the loss of protrusive actin structures, we measured F-actin levels with a flow cytometry-based assay in nonadherent A20 cells treated with ionomycin, ionomycin + EGTA, EGTA alone, or latrunculin B, a compound that disrupts actin filament organization. Ionomycin exposure induced a disintegration of actin fila- 
A

A20 cells

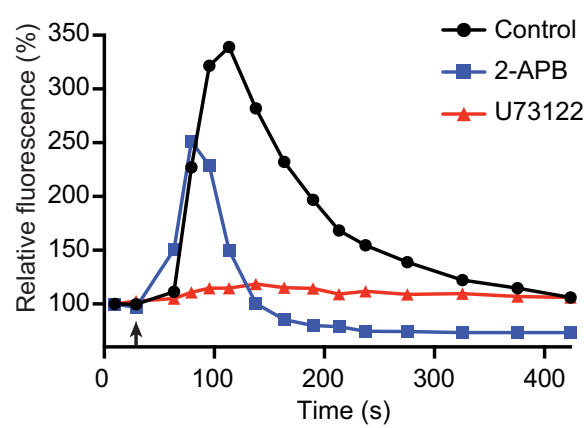

B

spleenic B cells

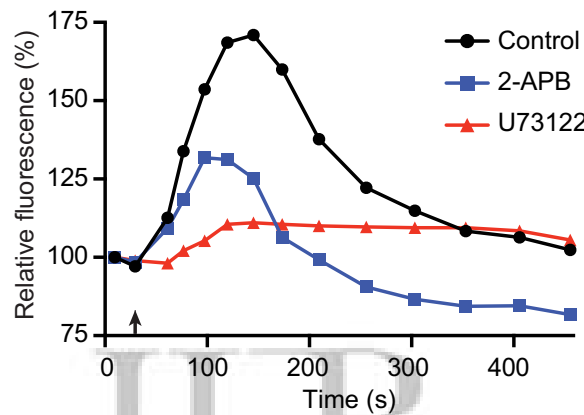

C

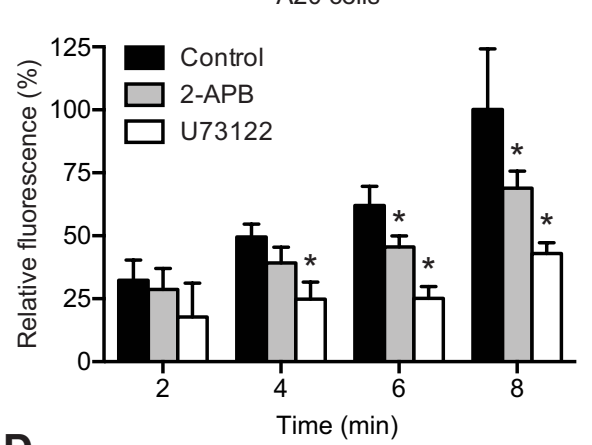

spleenic B cells

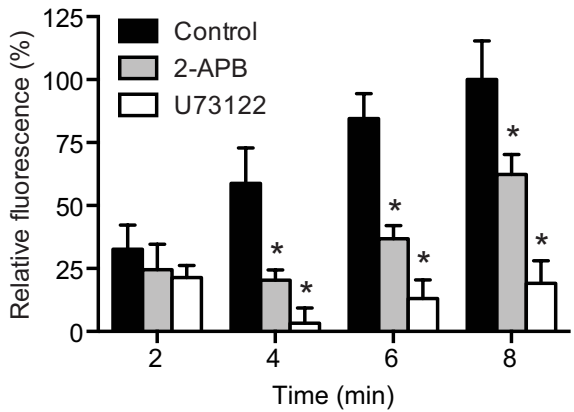

E

A20 cells

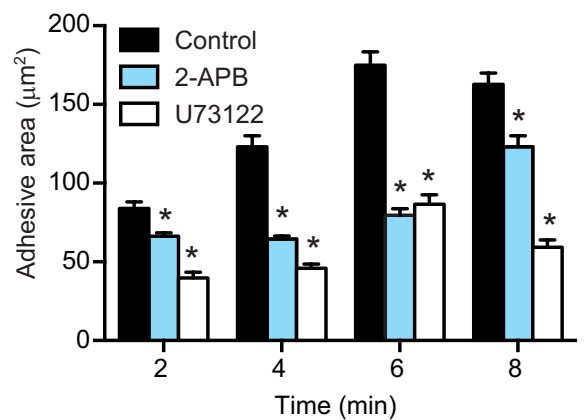

$\mathbf{F}$

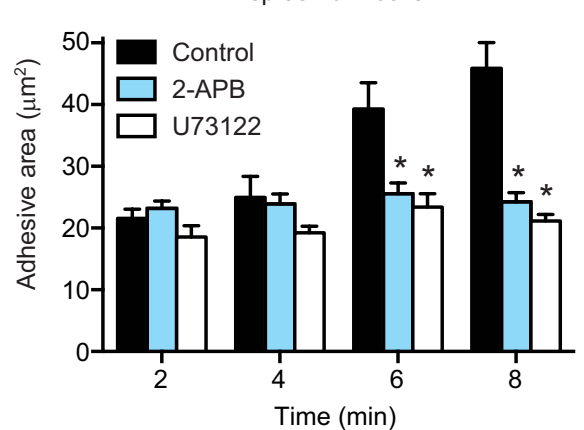

G

H

A20 cells

HUKOCVTE

spleenic B cells
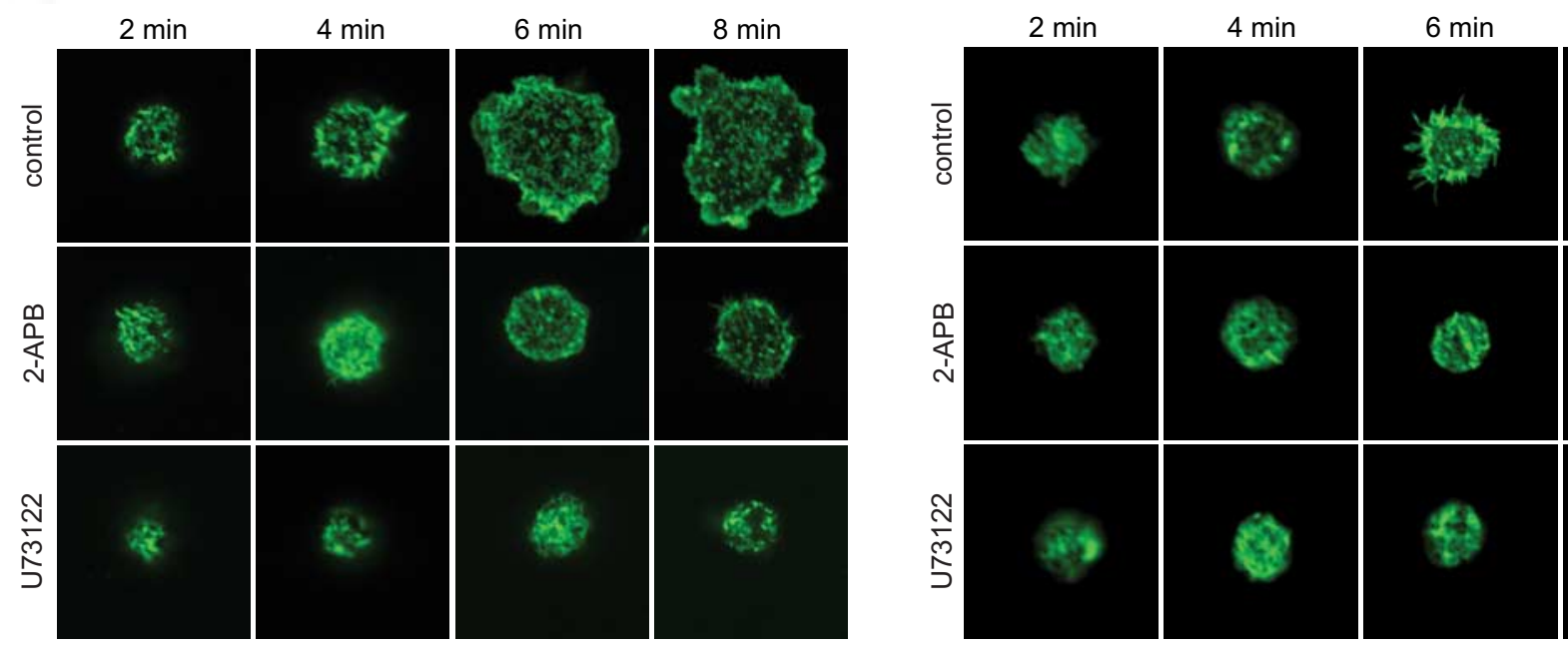

$8 \min$

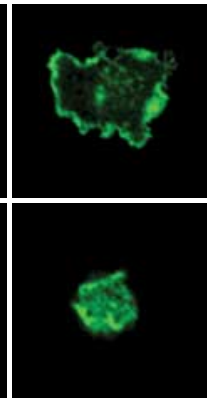

Figure 1. BCR-mediated calcium mobilization is indispensable for the B cell adhesion/spreading response. Calcium response of A20 cells (A) and splenic B cells (B) to anti-IgG or anti-IgM $(5 \mu \mathrm{g} / \mathrm{ml})$ stimulation, as detected by Fluo-4 fluorescence (left). Relative fluorescence of anti-Ig-coated surfaces after incubation for the given time ( $n=6$ in every case) with CellTracker Green-loaded A20 (C) or mouse primary B cells (D) is also shown (middle). Cells were pretreated with 2-APB or U73122 if indicated. All values were statistically tested by Student's unpaired $t$-test $(* P<0.05)$. Fluorescence values were normalized by taking the average of anti-Ig-coated control samples with 8 min incubation time as $100 \%$. Error bars represent the SEM. The contact area of A20 (E) and splenic B cells (F), determined in the above experiment in control and pretreated cells from CLSM images recorded at the given times ( $\mathrm{G}$ and $\mathrm{H}$, respectively), is also displayed (right).

ments (Fig. 2G) comparable with that of latrunculin B. The level of F-actin reduced to $60 \%$ after 1 min of treatment, whereas after $8 \mathrm{~min}$, it decreased to as low as $35 \%$. Interest- ingly, treatments with EGTA or ionomycin + EGTA, which were both found to lower cytoplasmic level of the free calcium (Fig. 2B and C), had an opposite effect; they induced a satura- 
A

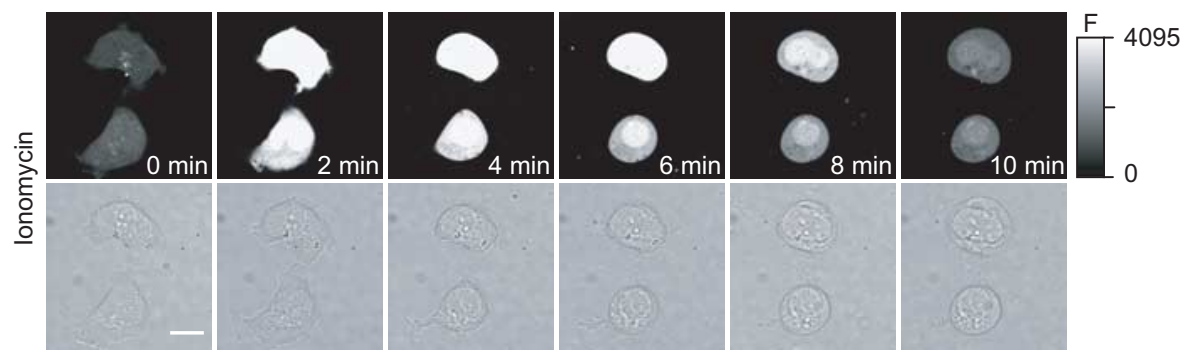

B
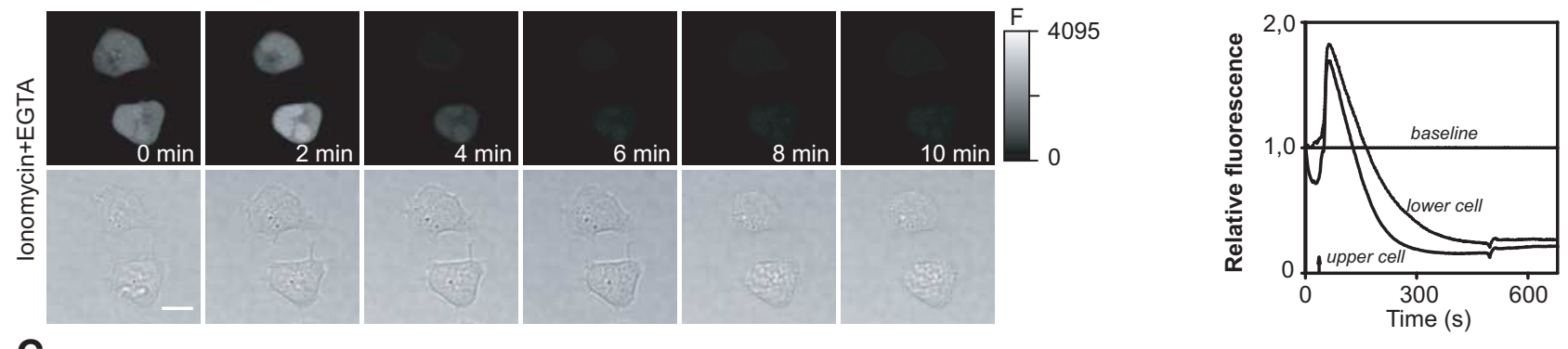

C

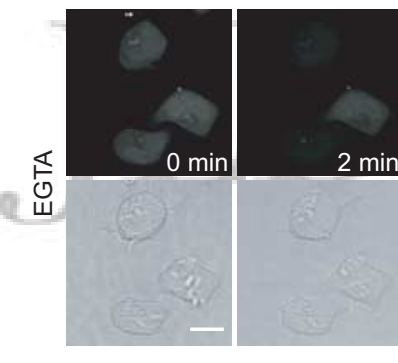

D

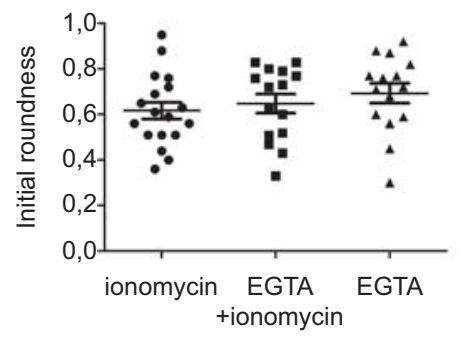

E

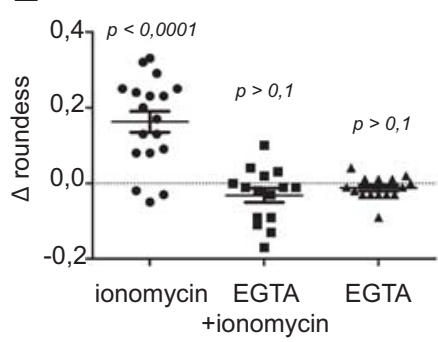

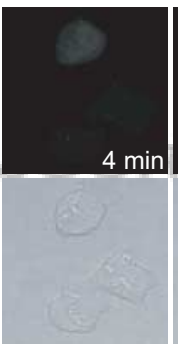

F
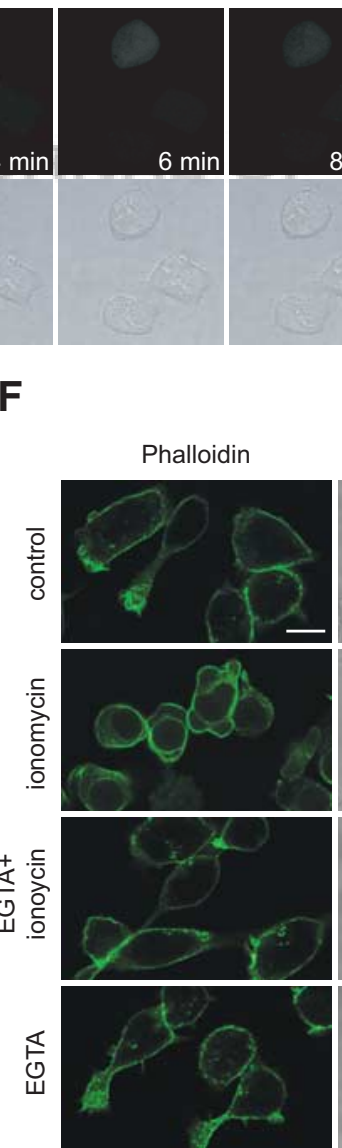
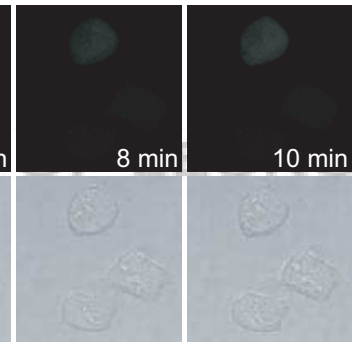

DIC

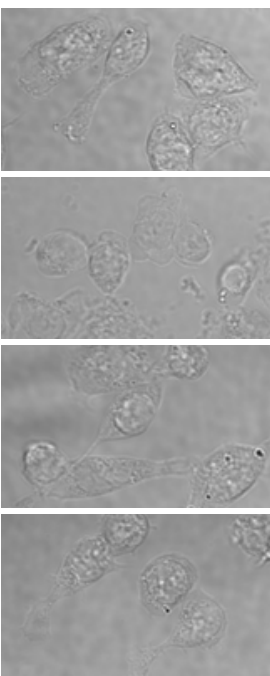

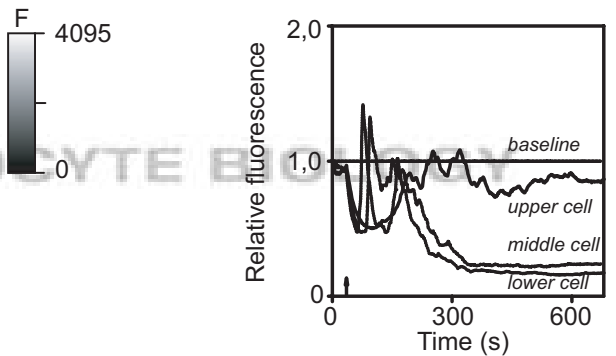

G

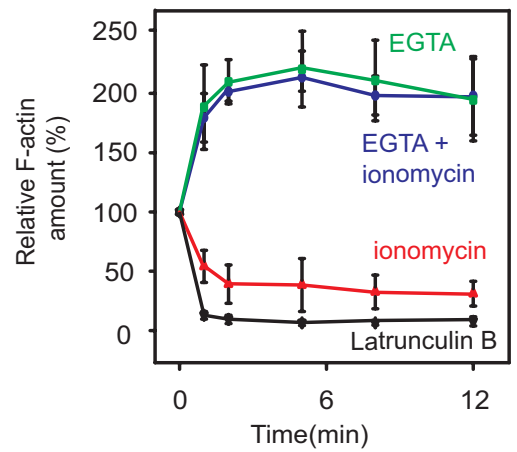

Figure 2. Calcium mobilization induces disassembly of the actin cytoskeleton in B cells. Calcium images of adherent, Fluo-4labeled A20 cells treated with ionomycin $(2 \mu \mathrm{g} / \mathrm{ml} ; \mathrm{A})$, ionomycin $(2 \mu \mathrm{g} / \mathrm{ml})+$ EGTA (2 mM; B), or EGTA $(2 \mathrm{mM})$ alone (C). Upper panels show the fluorescent images color-mapped with a color gradient from white (high fluorescence) to black (low fluorescence), as indicated by the color bar; lower panels are the DIC images. The relative fluorescence as a function of time is indicated on the right side. Arrows on the diagrams indicate the time-points of exposure. Original bars, $10 \mu \mathrm{m}$. Initial roundness of adherent A20 cells treated with ionomycin $(n=18)$, ionomycin + EGTA $(n=15)$, or EGTA alone $(n=15$; D) and alteration $(\Delta)$ of roundness after 12 min of the same treatments $($ E). 
tion curve-like growth in the amount of F-actin (Fig. 2G). After 2 min of treatment, the amount of F-actin had doubled and reached its saturation. These results suggest an inverse correlation between the cytoplasmic level of free calcium and the amount of F-actin. Thus, we concluded that changes in cytoplasmic-free $\mathrm{Ca}^{2+}$ level can regulate actin rearrangements in B cells.

\section{Cytoplasmic $\mathrm{Ca}^{2+}$ regulates production and disassembly of F-actin-based protrusive structures}

Finding that the cytoplasmic level of free $\mathrm{Ca}^{2+}$ can regulate the amount filamentary actin, we wanted to understand if it can specifically regulate the production of protrusive actin structures, such as lamellipodia. To address this question, A20 cells, stably expressing mCherry-actin, were loaded with the calcium indicator Fluo- 4 and investigated by time-lapse confocal microscopy. We induced calcium oscillations by chelating the extracellular calcium using EGTA and monitored the distribution of mCherry-actin. Calcium oscillations resulted in a pulsing production and disassembly of fillopodia-like structures (Fig. 3A and $\mathbf{B}$ and Supplemental Video 4). Plotting the level of cytosolic-free $\mathrm{Ca}^{2+}$ and the amount of mCherry-actin in the cortical regions of cells as a function of time revealed a "quasy periodical synchronicity" between the two signals. The amount of mCherry-actin in the boundary regions oscillated together with $\mathrm{Ca}^{2+}$ but with an opposite phase (Fig. 3C).

We quantified the interdependency of $\mathrm{Ca}^{2+}$ and actin signals by calculating NMI, a number between one and zero that measures the mutual dependence of these two variables. NMI values scattered $\sim 0.7$, reflecting a strong synchronicity between calcium and actin dynamics (Fig. 3D). The relevance of this strong phase locking was tested with the aim of a surrogate bootstrap technique and a subsequent adaptive Neyman's test. Synchronicity of the measured data proved to be highly significant $(P<0.000001)$ compared with the asynchronous surrogate data, and on the other hand, experimental NMIs differed much less from the fully synchronized surrogates $(P<0.0013)$.

Thus, we concluded that fillopodia production and disassembly in A20 B cells strongly depend on the actual concentration of cytoplasmic $\mathrm{Ca}^{2+}$. Lowering the cytoplasmic level correlates with fillopodia growth, whereas raising it drives fillopodium disassembly.

\section{Actin cytoskeleton reorganization is required for $\mathbf{B}$ cell spreading}

Our previous experiments have demonstrated that BCR-driven $\mathrm{Ca}^{2+}$ mobilization is crucial for $\mathrm{B}$ cell spreading. We also found that cytoplasmic $\mathrm{Ca}^{2+}$ regulates $\mathrm{F}$-actin rearrangements and controls the production and disassembly of protrusive actin structures. To confirm that actin rearrangements are a pre- requisite to $\mathrm{B}$ cell adhesion and spreading, we treated A20 cells and primary splenic B cells with increasing concentrations of Jasplakinolide, a compound that results in actin polymerization and actin filament stabilization [33, 34]. We quantified the ability of cells to adhere and spread to antigentethered surfaces after Jasplakinolide treatment. At lower concentrations of Jasplakinolide $(0.5 \mu \mathrm{M}$ for primary B cells; 2 $\mu \mathrm{M}$ for A20 cells), we observed a slight but significant $(P<0.0001)$ increase in the relative number of cells attaching to the anti-Ig-coated surface when compared with control cells (Fig. 4A and B). This may be a result of the effect of Jasplakinolide to enhance BCR diffusion in the plasma membrane and facilitate the polarization of BCRs to the contact surface in this concentration range [7]. Raising the concentration of Jasplakinolide induced a dose-dependent, saturating decline in the number of cells adhering to the anti-Ig-coated surfaces. We observed an $\sim 60 \%$ decrease ( $4 \mu \mathrm{M}$ Jasplakinolide) in the case of primary B cells (Fig. 4A) and an $\sim 80 \%$ decrease (16 $\mu \mathrm{M}$ Jasplakinolide) in the case of A20 cells (Fig. $4 \mathrm{~B})$ in the number of adherent cells at the saturating concentration when compared with untreated cells. Thus, we concluded that depolymerization of actin filaments is a prerequisite of $\mathrm{B}$ cell adhesion and spreading.

\section{Cofilin-1, a candidate to transmit $\mathrm{Ca}^{2+}$ signal to the actin cytoskeleton}

Cofilin is a major regulator of lamellipodia formation in several cell types [35] and has been shown to play an important role in controlling IS formation in T cells [36] and B cells [12]. It is a $19-\mathrm{kDa}$ actin-severing protein that may promote depolymerization and polymerization of actin filaments [37].

The activity of cofilin is negatively regulated by the phosphorylation of the Ser 3 residue, a modification that antagonizes its actin-binding ability [38, 39]. In resting cells, cofilin is phosphorylated and thereby, inactive. Elevation of the intracellular $\mathrm{Ca}^{2+}$ concentration stimulates cofilin dephosphorylation in various cell types via a direct or indirect interaction with the calcium-dependent phosphatase calcineurin [40-42]. Given the role of cofilin in B cell spreading and its calcium-dependent regulation in other cell types, we asked if cofilin can transmit the calcium signal to the actin cytoskeleton in B cells and thereby, be a link between BCR-mediated $\mathrm{Ca}^{2+}$ mobilization and $\mathrm{B}$ cell spreading.

Mouse primary B cells were stimulated with anti-IgM, cell lysates were prepared and subjected to Western blotting for anti-p-cofilin (Ser 3; Fig. 4C), and phosphorylation was quantified by densitometry ( $n=3$; Fig. $4 \mathrm{D}$ ). BCR engagement in control cells induced, on the average, an $\sim 60 \%$ dephosphorylation of cofilin after $2 \mathrm{~min}$, which was followed by a small but not significant rephosphorylation after $5 \mathrm{~min}$. When SOCE was abrogated with 2-APB, unstimulated cells had a lower basal

(F) Fluorescent (left) and DIC images (right) of control, ionomycin, EGTA + ionomycin, or EGTA-treated, adherent A20 B cells labeled with phalloidin-Alexa488 and recorded by CLSM (green: filamentous actin). Original bar, $10 \mu \mathrm{m}$. (G) Relative fluorescence of phalloidin-Alexa488 as a function of time in A20 cells treated with EGTA, EGTA + ionomycin, ionomycin, or latrunculin B $(2 \mu \mathrm{M})$ is also shown. Fluorescence values are normalized for the baseline. Mean \pm SD of three independent experiments is shown. 
A
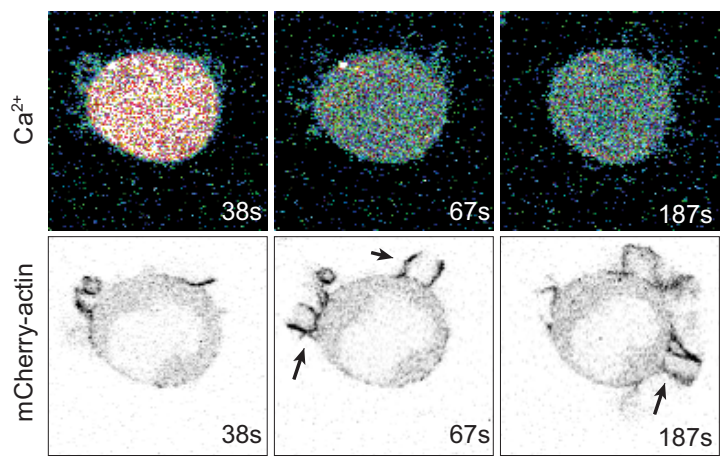
$187 \mathrm{~s}$

B
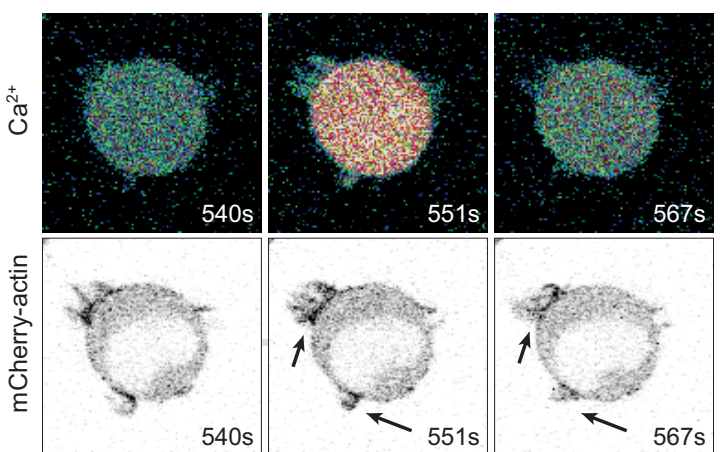

C

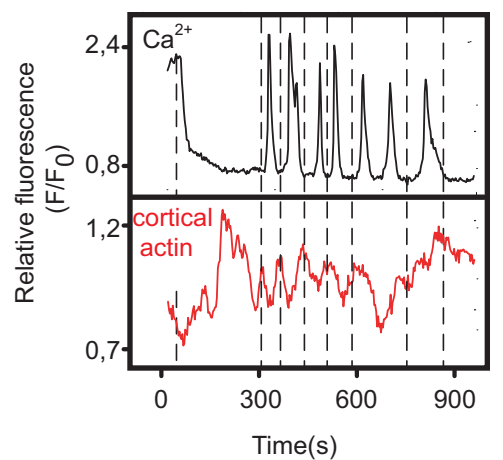

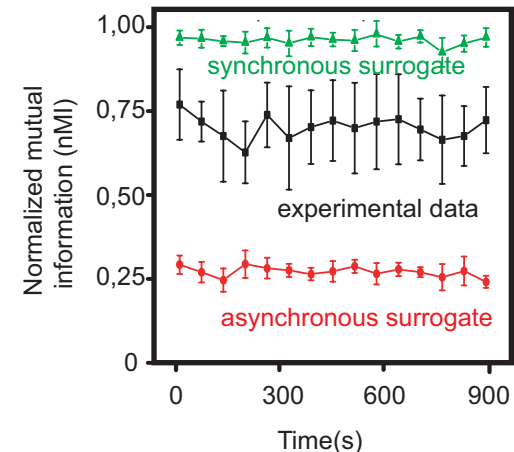

cence) to black (low fluorescence); arrows highlight filopodia]. Relative fluorescence $\left(\mathrm{F} / \mathrm{F}_{0}\right)$ of cortical F-actin and calcium as a function of time in mCherry-actin-expressing A20 cells loaded with Fluo-4 AM and exposed to EGTA (C). Fluorescence values were normalized to the average fluorescence of all time-lapse images. Interdependency of $\mathrm{Ca}^{2+}$ and actin signals described in $\mathrm{B}$, as measured by time-dependent (windowed) NMI, and NMI from experimental data (black), NMI of highly synchronized surrogates (green), and NMI of asynchronous surrogates (red) is shown (D) as mean \pm SD $(n=4)$. Time-lapse calcium imaging of mCherry-actin-expressing A20 cells after exposure to EGTA. Fluo-4 fluorescence is shown in the upper panels; mCherry-actin in the lower panels.

level of cofilin phosphorylation when compared with controls. However, BCR engagement in the 2-APB-treated cells did not lead to dephosphorylation of cofilin, but on the contrary, it induced significant rephosphorylation. Inhibition of PLC $\gamma$ by U73122 induced a roughly twofold hyperphosphorylation of cofilin in unstimulated and stimulated cells. Thus, we conclude that dephosphorylation of cofilin, a major regulator of $\mathrm{B}$ cell spreading [12], depends on BCR-mediated $\mathrm{Ca}^{2+}$ mobilization.

Dephosphorylation of the Ser 3 residue in cofilin was shown to be a prerequisite of B cell spreading [12]; little is known, however, about how cofilin-mediated F-actin severing occurs throughout B cell spreading [35]. To address this question, we stained primary B cells, spreading over anti-IgM-tethered surfaces for F-actin (phalloidin-Alexa488) and cofilin (anticofilin + anti-rabbit-Alexa647), and took images of the adherent contact zone using confocal microscopy (Fig. 4E). After 4 min of incubation on the antigen-tethered surface, the average diameter of the contact zone of cells was $6.0 \mu \mathrm{m} \pm 0.3 \mu \mathrm{m}$, and cofilin showed a strong colocalization with the clustered F-actin. After $6 \mathrm{~min}$, the average diameter of the adherent zone was $9 \mu \mathrm{m} \pm 0.7 \mu \mathrm{m}$, and the contact area could be clearly divided into a central zone with focal adhesion points and to a peripheral zone with lamellipodia densely packed with fila- mentous actin. Cofilin, at this stage, resided almost exclusively in the F-actin-rich lamellipodia (Fig. 4E). After $8 \mathrm{~min}$, cells have reached their maximum size or began contracting; the average diameter of the contact zone was $9 \mu \mathrm{m} \pm 0.3 \mu \mathrm{m}$. Cofilin started to pull back from the lamellipodia into the central zone. When Manders colocalization coefficients between F-actin and cofilin were plotted against the measured, average diameter of the contact zone, a clear connection of the two variables became outlined. Both the colocalization of cofilin to F-actin (Fig. 4F) and that of F-actin to cofilin (Fig. 4G) indicated a negative correlation toward the average diameter with very high colocalization in the initial phase of adhesion and spreading and a gradual decline as the stable contact was formed. These data suggest that actin-binding protein cofilin operates mostly throughout the adhesion and lamellipodia formation phase but draws back from the F-actin-rich regions once the stable contact/synapse is formed.

\section{DISCUSSION}

B cells may acquire antigens in soluble form or localized to the surface of APCs in the secondary lymphoid tissues. Contact with the surface-tethered antigen initiates a spreading re- 
A

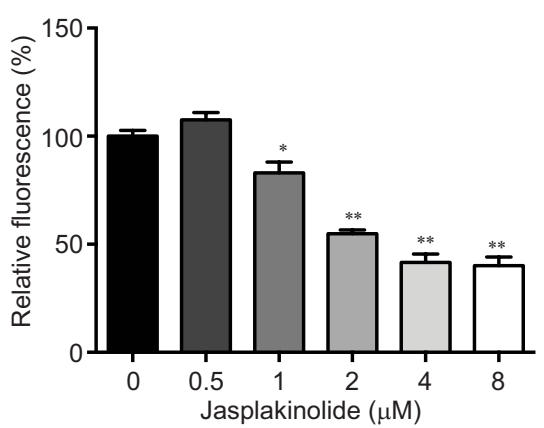

E

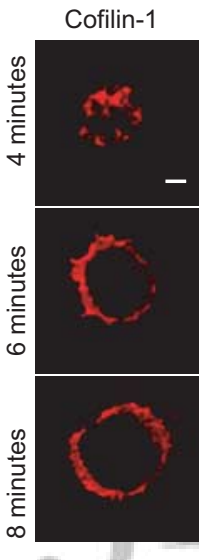

B

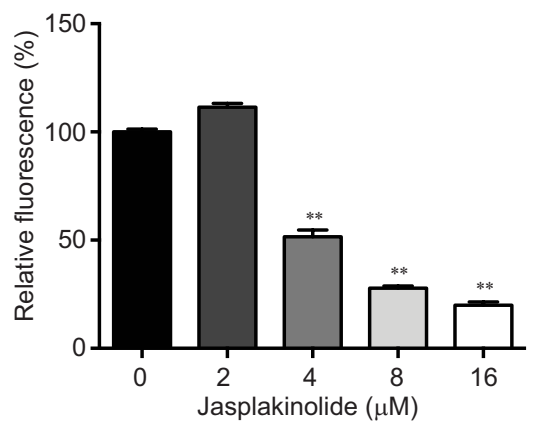

C

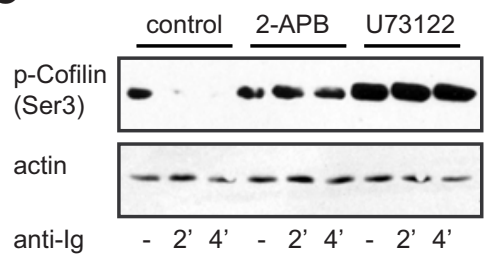

Figure 4. Actin remodeling protein cofilin-1 can transmit the BCR-induced calcium signal to the actin cytoskeleton during B cell spreading. Relative fluorescence of anti-Ig-coated surfaces after incubation with CellTracker Green-loaded mouse primary B cells (A) or A20 cells (B) for 8 min. Cells were pretreated with indicated concentrations of actin-stabilizing compound Jasplakinolide ( $n=6$ in every case). Fluorescence was normalized for the untreated control samples. Error bars represent SEM. Detection of cofilin phosphorylation by Western blotting in mouse primary B cells (C). Cells were preincubated with SOCE inhibitor 2-APB or PLC inhibitor U73122. Semiquantitative analysis of the Western blots by densitometry (D). OD is normalized for unstimulated control samples. Immunofluorescence analysis of mouse primary B cells subjected to anti-IgM-coated surfaces (E). After incubation for the given time, cells were fixed and stained, and images of the adherent zone were taken. Cofilin (red), F-actin (green) fluorescence, and their merged image are shown from left to right, and the fourth column shows DIC images. Original bar, $2 \mu \mathrm{m}$. Colocalization of cofilin to F-actin (F) and F-actin to cofilin (G), measured by the Manders coefficient as a function of adherent zone diameter (d), are also shown.

sponse [3]. B cells adhere to the surface and grow protrusive radial membrane structures, lamellipodia, by generating newly formed branched actin filaments [2]. Signal transduction proteins PLC $\gamma 2$, Btk and Blnk, elements of the BCR-mediated $\mathrm{Ca}^{2+}$ mobilization pathway, were implicated to be indispensable in spreading of B cells [7]. Based on these, we hypothesized a direct role for intracellular $\mathrm{Ca}^{2+}$ in regulating $\mathrm{B}$ cell spreading.

We measured adhesion and spreading of B cells on antigentethered surfaces in the presence or absence of $\mathrm{Ca}^{2+}$ influx or $\mathrm{Ca}^{2+}$ release from the intracellular stores. We used the compound 2-APB to inhibit $\mathrm{Ca}^{2+}$ influx via CRAC channels and the compound U73122, an inhibitor of PLC $\gamma$, to completely abolish BCR-mediated $\mathrm{Ca}^{2+}$ mobilization. Whereas loss of $\mathrm{Ca}^{2+}$ influx severely reduced the number of $\mathrm{B}$ cells adhering to the antigen and the size of the adhesive area, full inhibition of BCR-induced $\mathrm{Ca}^{2+}$ mobilization abolished $\mathrm{B}$ cell adhesion and spreading almost completely. Previous reports implicated that knockdown of elements in the PLC $\gamma$ pathway impairs lamellipodia formation during B cell contacts [7] and in other cell types $[43,44]$. We confirmed these results and showed, in addition, that loss of lamellipodia formation in B cells with no functional PLC $\gamma$ is a result of loss of BCR-induced $\mathrm{Ca}^{2+}$ mobilization. Similar results can be obtained with a milder approach, inhibiting $\mathrm{Ca}^{2+}$ influx only but leaving $\mathrm{Ca}^{2+}$ release from the ER stores intact by using the CRAC channel inhibitor 2-APB. Furthermore, our results highlight that not only B cell spreading but also, prior to that, $\mathrm{B}$ cell adhesion to the antigens relies on the secondary messenger $\mathrm{Ca}^{2+}$.

We asked how cytoplasmic $\mathrm{Ca}^{2+}$ is involved in the regulation of adhesion and spreading of B cells. Previous reports have indicated that experimentally induced $\mathrm{Ca}^{2+}$ transients evoked by $\mathrm{Ca}^{2+}$ ionophores, such as ionomycin and A23187, can induce substantial changes in the actin cytoskeleton in several cell types [20-22]. We hypothesized that $\mathrm{Ca}^{2+}$ might mediate actin rearrangements in B cells and thereby, regulate 
synapse formation. To address this question, we modeled BCRinduced $\mathrm{Ca}^{2+}$ mobilization, keeping $\mathrm{Ca}^{2+}$-independent signaling pathways downstream of PLC $\gamma$ inactive with the use of the $\mathrm{Ca}^{2+}$ ionophore ionomycin. When adherent A20 B cells were exposed to ionomycin, cells lost actin-based lamellipodia, which was accompanied by a morphological transition from a spread-out cell shape to a rounded shape. This effect could be prevented when extracellular $\mathrm{Ca}^{2+}$ was chelated with EGTA. We observed a similar disintegration of filamentary actin upon ionomycin-induced $\mathrm{Ca}^{2+}$ transients when cellular F-actin content was directly determined. Additionally, lowering the cytoplasmic $\mathrm{Ca}^{2+}$ concentration had an opposite effect, resulting in actin polymerization. These results suggest that cytoplasmic $\mathrm{Ca}^{2+}$ can regulate the reorganization of the actin cytoskeleton in $\mathrm{B}$ cells.

We achieved to visualize reorganization of the cortical actin cytoskeleton upon changing cytoplasmic calcium levels in live cells by inducing $\mathrm{Ca}^{2+}$ oscillations in mCherry-actin-expressing A20 cells. EGTA evoked calcium oscillations that provoked the production and disassembly of fillopodia. The maximum amount of fillopodia in the cortical region was detected when the free cytoplasmic calcium level was the lowest, whereas we observed a disintegration of fillopodia upon $\mathrm{Ca}^{2+}$ transients. Statistical analysis of the interdependency of the amount of cortical actin and cytoplasmic level of free $\mathrm{Ca}^{2+}$ revealed a strong coupling of the two variables. We could show that actin and calcium dynamics are strongly synchronized in living B cells. Whereas calcium release events induce disintegration of protrusive actin structures, calcium sequestering induces filamentous actin growth.

The effect of cytoplasmic-free $\mathrm{Ca}^{2+}$ on cell shape and actin cytoskeleton was already reported in various cell types [20, 21, 45-47]; calcium was indicated to take part in the regulation of actin-defined movements, such as cell motility, chemotaxis, and polarization [48-52], but to our knowledge, this is the first time that such a phenomenon was described in important adaptive elements of the immune system in the B cells. No direct evidence has been reported so far on the specific inverse correlation between the cytoplasmic level of free calcium and the amount of F-actin. Our results suggest a mechanism by which BCR-induced calcium mobilization mediates initial F-actin depolymerization in B cells, generating new filament endings, whereas local $\mathrm{Ca}^{2+} \mathrm{se}^{2}$ questering may induce the polymerization of actin and the formation of protrusive actin structures.

Cofilin is known to regulate lamellipodia [53-56] and synapse formation in many cell types, including B lymphocytes [12]. Cofilin is regulated by phosphorylation on a negative regulatory Ser 3 residue. Dephosphorylation of this residue was shown to depend on cytoplasmic calcium in several cell types [40-42]. Therefore, we hypothesize that cofilin might be a link between the BCR-induced calcium release and the lamellipodia formation in B cells. To address this question, we investigated dephosphorylation of cofilin upon BCR engagement and found that ER-mediated $\mathrm{Ca}^{2+}$ release and SOCE are required for activation of cofilin in B cells. This result is in accordance with that seen in other cell types [40-42].

Investigating the localization of cofilin during B cell spreading, we observed that in the growing phase, cofilin resides in the F-actin-rich region of the adherent zone. The more spread out the synapse became, the less likely cofilin was found in the lamellipodia. This is in accordance with the described role of cofilin in lamellipodia formation [53-56]. In the initial phase of lamellipodia formation, cofilin mediates the formation new, fast-growing barbed ends by severing pre-exsisting actin filaments $[57,58]$. At this phase, cofilin can also modulate the structure of the lamellipodia by competing with filamentbranching protein complex Arp2/3 for actin binding [59] and favoring the assembly of unbranched filaments. In the late phase, when G-actin monomers run short in the lamellipodia, the most important role of cofilin may be to supply an abundant pool of cytoplasmic actin monomers [60]; thus, cofilin withdraws from the lamellipodia.

In conclusion, we argue that BCR-mediated calcium mobilization regulates actin cytoskeleton rearrangements in $\mathrm{B}$ cells and is indispensable for B cell adhesion and spreading to antigen-tethered surfaces. Our findings highlight a link between calcium signaling and actin rearrangements that may go beyond the particular process of B cell spreading. However, further studies will be required to elucidate the exact mechanism that links cytoplasmic $\mathrm{Ca}^{2+}$ to actin dynamics.

\section{AUTHORSHIP}

M.M. designed, performed research, and drafted the manuscript. D.M., E.K., and A.E.S. performed experiments. Á.E. helped to design experiments. N.S. performed mathematical modeling analysis. J.M. and G.S. designed the experiments and drafted the manuscript.

\section{ACKNOWLEDGMENTS}

This work was supported by the Hungarian National Science Fund (OTKA) and the National Development Agency (NFU; CK80283 to Á.E., CK80935 to J.M., and CK80689 to G.S.). The European Social Fund has provided financial support to the project under Grant Agreement No. TÁMOP 4.2.1./B-09/1/ KMR-2010-0003. Support of the Hungarian Academy of Sciences is also acknowledged. We thank Peter Nielsen and Miklos Nyitrai for comments on the manuscript and Michael Reth for his kind support, as well as Márta Pásztor for the skillful technical assistance.

\section{REFERENCES}

1. Huang, N. N., Han, S. B., Hwang, I. Y., Kehrl, J. H. (2005) B cells productively engage soluble antigen-pulsed dendritic cells: visualization of live-cell dynamics of B cell-dendritic cell interactions. J. Immunol. 175, 7125-7134.

2. Fleire, S. J., Goldman, J. P., Carrasco, Y. R., Weber, M., Bray, D., Batista, F. D. (2006) B cell ligand discrimination through a spreading and contraction response. Science 312, 738-741.

3. Batista, F. D., Iber, D., Neuberger, M. S. (2001) B cells acquire antigen from target cells after synapse formation. Nature 411, 489-494.

4. Monks, C. R., Freiberg, B. A., Kupfer, H., Sciaky, N., Kupfer, A. (1998) Three-dimensional segregation of supramolecular activation clusters in T cells. Nature $395,82-86$.

5. Dustin, M. L. (2007) Cell adhesion molecules and actin cytoskeleton at immune synapses and kinapses. Curr. Opin. Cell Biol. 19, 529-533.

6. Grakoui, A., Bromley, S. K., Sumen, C., Davis, M. M., Shaw, A. S., Allen, P. M., Dustin, M. L. (1999) The immunological synapse: a molecular machine controlling T cell activation. Science 285, 221-227.

7. Weber, M., Treanor, B., Depoil, D., Shinohara, H., Harwood, N. E., Hikida, M., Kurosaki, T., Batista, F. D. (2008) Phospholipase C- $\gamma 2$ and Vav cooperate within signaling microclusters to propagate B cell spreading in response to membrane-bound antigen. J. Exp. Med. 205, 853-868. 
8. Goley, E. D., Welch, M. D. (2006) The ARP2/3 complex: an actin nucleator comes of age. Nat. Rev. Mol. Cell. Biol. 7, 713-726.

9. Pollard, T. D., Borisy, G. G. (2003) Cellular motility driven by assembly and disassembly of actin filaments. Cell 112, 453-465.

10. Billadeau, D. D., Nolz, J. C., Gomez, T. S. (2007) Regulation of T-cell activation by the cytoskeleton. Nat. Rev. Immunol. 7, 131-143.

11. Lin, K. B., Freeman, S. A., Zabetian, S., Brugger, H., Weber, M., Lei, V., DangLawson, M., Tse, K. W., Santamaria, R., Batista, F. D., Gold, M. R. (2008) The rap GTPases regulate $B$ cell morphology, immune-synapse formation, and signaling by particulate B cell receptor ligands. Immunity 28, 75-87.

12. Freeman, S. A., Lei, V., Dang-Lawson, M., Mizuno, K., Roskelley, C. D., Gold, M. R. (2011) Cofilin-mediated F-actin severing is regulated by the Rap GTPase and controls the cytoskeletal dynamics that drive lymphocyte spreading and BCR microcluster formation. J. Immunol. 187, 5887-5900.

13. Bos, J. L. (2005) Linking Rap to cell adhesion. Curr. Opin. Cell Biol. 17, $123-128$.

14. Fu, C., Turck, C. W., Kurosaki, T., Chan, A. C. (1998) BLNK: a central linker protein in B cell activation. Immunity 9, 93-103.

15. Hashimoto, S., Iwamatsu, A., Ishiai, M., Okawa, K., Yamadori, T., Matsushita, M., Baba, Y., Kishimoto, T., Kurosaki, T., Tsukada, S. (1999) Identification of the SH2 domain binding protein of Bruton's tyrosine kinase as BLNK-functional significance of Btk-SH2 domain in B-cell antigen receptor-coupled calcium signaling. Blood 94, 2357-2364.

16. Scharenberg, A. M., Humphries, L. A., Rawlings, D. J. (2007) Calcium signalling and cell-fate choice in B cells. Nat. Rev. Immunol. 7, 778-789.

17. Prakriva, M., Lewis, R. S. (2001) Potentiation and inhibition of $\mathrm{Ca}(2+)$ release-activated $\mathrm{Ca}(2+)$ channels by 2-aminoethyldiphenyl borate (2APB) occurs independently of IP(3) receptors. J. Physiol. 536, 3-19.

18. Parekh, A. B., Penner, R. (1997) Store depletion and calcium influx. Physiol. Rev. 77, 901-930.

19. Feske, S. (2007) Calcium signalling in lymphocyte activation and disease. Nat. Rev. Immunol. 7, 690-702

20. Yoneda, M., Nishizaki, T., Tasaka, K., Kurachi, H., Miyake, A., Murata, Y. (2000) Changes in actin network during calcium-induced exocytosis in permeabilized GH3 cells: calcium directly regulates F-actin disassembly. J. Endocrinol. 166, 677-687.

21. Li, C., Fultz, M. E., Parkash, J., Rhoten, W. B., Wright, G. L. (2001) Ca2+-dependent actin remodeling in the contracting A7r5 cell. J. Muscle Res. Cell. Motil. 22, 521-534.

22. Rotrosen, D., Gallin, J. I. (1986) Histamine type I receptor occupancy increases endothelial cytosolic calcium, reduces F-actin, and promotes albumin diffusion across cultured endothelial monolavers. J. Cell Biol. 103, 2379-2387.

23. Yin, H. L., Stossel, T. P. (1979) Control of cytoplasmic actin gel-sol transformation by gelsolin, a calcium-dependent regulatory protein. $\mathrm{Na}$ ture 281, 583-586.

24. Witke, W., Hofmann, A., Koppel, B., Schleicher, M., Noegel, A. A. (1993) The $\mathrm{Ca}(2+)$-binding domains in non-muscle type $\alpha$-actinin: biochemical and genetic analysis. J. Cell Biol. 121, 599-606.

25. Herzog, S., Jumaa, H. (2007) The $\mathrm{N}$ terminus of the non-T cell activation linker (NTAL) confers inhibitory effects on pre-B cell differentiation. J. Immunol. 178, 2336-2343.

26. Ketteler, R., Glaser, S., Sandra, O., Martens, U. M., Klingmuller, U. (2002) Enhanced transgene expression in primitive hematopoietic progenitor cells and embryonic stem cells efficiently transduced by optimized retroviral hybrid vectors. Gene Ther. 9, 477-487.

27. Syverud, K., Chinga, G., Johnssen, P. O., Leirset, I., Wiik, K. (2007) Analysis of lint particles from full-scale printing trials. Appita J. 60, 286-290.

28. Maders, E. M. M., Verbeek, F. J., Aten, J. A. (1993) Measurement of colocalization of objects in dual-color confocal images. J. Microscopy 169, 375-382.

29. Majstoravich, S., Zhang, J., Nicholson-Dykstra, S., Linder, S., Friedrich, W., Siminovitch, K. A., Higgs, H. N. (2004) Lymphocyte microvilli are dynamic, actin-dependent structures that do not require Wiskott-Aldrich syndrome protein (WASp) for their morphology. Blood 104, 1396-1403.

30. Treanor, B., Depoil, D., Gonzalez-Granja, A., Barral, P., Weber, M., Dushek, O., Bruckbauer, A., Batista, F. D. (2010) The membrane skeleton controls diffusion dynamics and signaling through the B cell receptor. Immunity 32, 187-199.

31. Hao, S., August, A. (2005) Actin depolymerization transduces the strength of B-cell receptor stimulation. Mol. Biol. Cell. 16, 2275-2284

32. Dedkova, E. N., Sigova, A. A., Zinchenko, V. P. (2000) Mechanism of action of calcium ionophores on intact cells: ionophore-resistant cells. Membr. Cell Biol. 13, 357-368.

33. Bubb, M. R., Spector, I., Beyer, B. B., Fosen, K. M. (2000) Effects of Jasplakinolide on the kinetics of actin polymerization. An explanation for certain in vivo observations. J. Biol. Chem. 275, 5163-5170.

34. Holzinger, A. (2009) Jasplakinolide: an actin-specific reagent that promotes actin polymerization. Methods Mol. Biol. 586, 71-87.

35. Oser, M., Condeelis, J. (2009) The cofilin activity cycle in lamellipodia and invadopodia. J. Cell. Biochem. 108, 1252-1262.

36. Eibert, S. M., Lee, K. H., Pipkorn, R., Sester, U., Wabnitz, G. H., Giese, T., Meuer, S. C., Samstag, Y. (2004) Cofilin peptide homologs interfere with immunological synapse formation and T cell activation. Proc. Natl. Acad. Sci. USA 101, 1957-1962.
37. Hao, J. J., Wang, G., Pisitkun, T., Patino-Lopez, G., Nagashima, K., Knepper, M. A., Shen, R. F., Shaw, S. (2008) Enrichment of distinct microfilament-associated and GTP-binding-proteins in membrane $/ \mathrm{mi}-$ crovilli fractions from lymphoid cells. J. Proteome Res. 7, 2911-2927.

38. Jovceva, E., Larsen, M. R., Waterfield, M. D., Baum, B., Timms, J. F (2007) Dynamic cofilin phosphorylation in the control of lamellipodial actin homeostasis. J. Cell Sci. 120, 1888-1897.

39. DesMarais, V., Ghosh, M., Eddy, R., Condeelis, J. (2005) Cofilin takes the lead. J. Cell Sci. 118, 19-26.

40. Wang, Y., Shibasaki, F., Mizuno, K. (2005) Calcium signal-induced cofilin dephosphorylation is mediated by Slingshot via calcineurin. J. Biol. Chem. 280, 12683-12689.

41. Klee, C. B., Ren, H., Wang, X. (1998) Regulation of the calmodulin-stimulated protein phosphatase, calcineurin. J. Biol. Chem. 273, 13367-13370.

42. Ambach, A., Saunus, J., Konstandin, M., Wesselborg, S., Meuer, S. C. Samstag, Y. (2000) The serine phosphatases PP1 and PP2A associate with and activate the actin-binding protein cofilin in human T lymphocytes. Eur. J. Immunol. 30, 3422-3431.

43. Wonerow, P., Pearce, A. C., Vaux, D. J., Watson, S. P. (2003) A critical role for phospholipase $\mathrm{C} \gamma 2$ in $\alpha \mathrm{IIb} \beta 3$-mediated platelet spreading. $J$. Biol. Chem. 278, 37520-37529.

44. Choi, J. H., Yang, Y. R., Lee, S. K., Kim, I. S., Ha, S. H., Kim, E. K., Bae, Y. S., Ryu, S. H., Suh, P. G. (2007) Phospholipase C- $\gamma 1$ potentiates integrin-dependent cell spreading and migration through Pyk2/paxillin activation. Cell. Signal. 19, 1784-1796.

45. Furukawa, R., Maselli, A., Thomson, S. A., Lim, R. W., Stokes, J. V., Fechheimer, M. (2003) Calcium regulation of actin crosslinking is important for function of the actin cytoskeleton in Dictyostelium. J. Cell Sci. 116, 187-196.

46. Glenney J. R., Jr., Kaulfus, P., Weber, K. (1981) F actin assembly modulated by villin: $\mathrm{Ca}++$-dependent nucleation and capping of the barbed end. Cell 24, 471-480

47. Zaffran, Y., Lepidi, H., Benoliel, A. M., Capo, C., Bongrand, P. (1993) Role of calcium in the shape control of human granulocytes. Blood Cells 19, 115-129.

48. Lee, J., Ishihara, A., Oxford, G., Johnson, B., Jacobson, K. (1999) Regulation of cell movement is mediated by stretch-activated calcium channels. Nature 400, 382-386.

49. Mandeville, J. T., Ghosh, R. N., Maxfield, F. R. (1995) Intracellular calcium levels correlate with speed and persistent forward motion in migrating neutrophils. Biophys. J. 68, 1207-1217.

50. Huttenlocher, A., Palecek, S. P., Lu, Q., Zhang, W., Mellgren, R. L., Lauffenburger, D. A., Ginsberg, M. H., Horwitz, A. F. (1997) Regulation of cell migration by the calcium-dependent protease calpain. J. Biol. Chem. 272, 32719-32722.

51. Brundage, R. A., Fogarty, K. E., Tuft, R. A., Fay, F. S. (1993) Chemotaxis of newt eosinophils: calcium regulation of chemotactic response. Am.J. Physiol. 265, C1527-C1543.

52. Brundage, R. A., Fogarty, K. E., Tuft, R. A., Fav, F. S. (1991) Calcium gradients underlying polarization and chemotaxis of eosinophils. Science 254, 703-706.

53. Carlier, M. F., Ressad, F., Pantaloni, D. (1999) Control of actin dynamics in cell motility. Role of ADF/cofilin. J. Biol. Chem. 274, 33827-33830.

54. Mazur, A. J., Gremm, D., Dansranjavin, T., Litwin, M., Jockusch, B. M., Wegner, A., Weeds, A. G., Mannherz, H. G. (2010) Modulation of actin filament dynamics by actin-binding proteins residing in lamellipodia. Eur. J. Cell Biol. 89, 402-413.

55. Bugyi, B., Carlier, M. F. (2010) Control of actin filament treadmilling in cell motility. Annu. Rev. Biophys. 39, 449-470.

56. Ghosh, M., Song, X., Mouneimne, G., Sidani, M., Lawrence, D. S., Condeelis, J. S. (2004) Cofilin promotes actin polymerization and defines the direction of cell motility. Science 304, 743-746.

57. Zebda, N., Bernard, O., Bailly, M., Welti, S., Lawrence, D. S., Condeelis, J. S. (2000) Phosphorylation of ADF/cofilin abolishes EGF-induced actin nucleation at the leading edge and subsequent lamellipod extension. $J$. Cell Biol. 151, 1119-1128.

58. Condeelis, J. (2001) How is actin polymerization nucleated in vivo? Trends Cell Biol. 11, 288-293.

59. Chan, C., Beltzner, C. C., Pollard, T. D. (2009) Cofilin dissociates Arp2/3 complex and branches from actin filaments. Curr. Biol. 19, 537-545.

60. Kiuchi, T., Ohashi, K., Kurita, S., Mizuno, K. (2007) Cofilin promotes stimulus-induced lamellipodium formation by generating an abundant supply of actin monomers. J. Cell Biol. 177, 465-476.

61. Rosenblum, M. G., Pikovsky, A. S., Kurths, J. (1996) Phase synchronization of chaotic oscillators. Phys. Rev. Lett. 76, 1804-1807.

62. Palus, M., Hoyer, D. (1998) Detecting nonlinearity and phase synchronization with surrogate data. IEEE Eng. Med. Biol. Mag. 17, 40-45.

63. Inglot, T., Ledwina, T. (1996) Asymptotic optimality of data-driven Neyman's tests for uniformity. Ann. Statist. 24, 1982-2019.

\section{KEY WORDS:}

$\mathrm{B}$ cell spreading $\cdot$ membrane-bound antigens $\cdot B$ cell activation

$\cdot \mathrm{Ca}^{2+}$ signal $\cdot$ cofilin 


\section{AUTHOR QUERIES}

\section{AUTHOR PLEASE ANSWER ALL QUERIES}

AQ1- Is this roundness definition as meant?

AQ2 - Since the journal refrains from using one, the Appendix was moved into the Materials and Methods section of the text. Okay as edited?

AQ3 - Is it okay that $p(x)$ and $p(y)$ and $H(X)+H(Y)$ (see next paragraph) are not used this way in the equation?

AQ4 - Or quasi?

AQ5- To what do left, middle, and right refer, used in this legend in parentheses? It appears each panel has a letter title, not placement identification?

AQ6 - Do you need to describe symbols above bars in Fig. 4A and B?

AQ7- Is this the correct description for the use of " $\mathrm{d}$ " as the horizontal label in Fig. 4F and G?

AQ8 - OPTIONAL: Please provide your Twitter profile URL or the Twitter profile URL for your laboratory or department. 